
on the Air Quality of Kolkata and Howrah, West Bengal, India

Mohan Sarkar ( $\square$ mohansrkrs@gmail.com )

Visva-Bharati, Santiniketan

\title{
Anupam Das
}

Panihati Mahavidyalaya

Sutapa Mukhopadhyay

Visva-Bhrati, Santiniketan

\section{Research Article}

Keywords: COVID-19, India, Lockdown, Pollutants, Air quality, ANOVA

Posted Date: July 6th, 2020

DOI: https://doi.org/10.21203/rs.3.rs-38142/v1

License: (c) (i) This work is licensed under a Creative Commons Attribution 4.0 International License. Read Full License

Version of Record: A version of this preprint was published at Environment, Development and Sustainability on September 22nd, 2020. See the published version at https://doi.org/10.1007/s10668-020-00985-7. 


\section{Abstract}

The worldwide spread of COVID-19 caused a nationwide lockdown in India from $24^{\text {th }}$ March 2020 and was further extended up to 3rd May 2020 to break off the transmission of novel Coronavirus. The study is designed to assess the changes in air quality from the pre lockdown period to the during lockdown period in Kolkata and Howrah municipal corporation, West Bengal, India. GIS-based techniques include the spatial and temporal distribution of pollutants using interpolation method, on the other hand, statistical methods like Analysis of Variance (ANOVA) was applied to determine the mean differences two phases and correlation matrix helps to understand the changing association of the pollutants in pre and during-lockdown phases. Significant correlations have been found among the pollutants, ANOVA (Two-Way) has shown the significant mean difference of NAQI between the two phases, $F(1,611)=465.723, p<0.0001$; pairwise comparison for Ballygunj has shown the highest mean difference 108.194 at $p<0.0001$ significant level between lockdown and pre lockdown phase. Significant positive correlation has been found between $\mathrm{PM}_{2.5}, \mathrm{PM} 10(0.99 *)$; $\mathrm{PM}_{2.5}$, $\mathrm{NO}_{2}\left(0.81^{\star}\right) ; \mathrm{PM}_{10}, \mathrm{NO}_{2}\left(0.81^{*}\right) ; \mathrm{CO}, \mathrm{NO}_{2}\left(0.77^{\star}\right)$ and some negative correlations have also been found between $\mathrm{O}_{3}, \mathrm{NO}$ $(-0.15) ; \mathrm{O}_{3}$ and $\mathrm{NH}_{3}(-0.36)$ in the pre lockdown phase. The reduction amount of mean concentration from the pre lockdown phase to during lockdown of the main pollutants like $\mathrm{PM}_{2.5}, \mathrm{PM}_{10}$ and $\mathrm{NO}_{2}$ are $\sim 58.71 \%, ~ 57.92 \%$ and $\sim 55.23 \%$. Near RBU constant emission of $\mathrm{PM}_{2.5}, 10$ and $\mathrm{NO}_{2}$ have been recorded due to the nearby Cossipore thermal power station.

\section{Introduction}

In December 2019, a disease, later named COVID-19, was identified in Wuhan of China and within three months more than 100 countries have been affected with devastating consequences (Q. Wang and Su 2020; WHO 2020). On March 11,2020 , it was found that the spread of COVID-19 is caused by the new Coronavirus SARS-CoV-2 and it was announced as a pandemic (Figueiredo et al. 2020). The first confirmed case of COVID-19 in India was identified on $30^{\text {th }}$ January 2020 in Kerala and hiked to three by $3^{\text {rd }}$ February when three students returned from Wuhan, China and the first death was recorded on 12 March. Till $3^{\text {rd }}$ May, 2020 cumulative number of total infection by COVID-19 was more than 40 thousand across India (GOI 2020). West Bengal the fourth-most densely inhabited state in the country recorded the first positive case of COVID-19 on 17 $7^{\text {th }}$ March2020 after a United Kingdom-returned student tested positive. To avert the infection, countries have strictly restricted the movement of people and transportation; reduce human interactions, enforcing strict quarantine, prohibiting large-scale private and public gatherings, encouraging social-distancing, restricting private and public transportations and economic behavior (Fernandes 2020; He et al. 2020; Q. Wang and Su 2020).

India has been following a nationwide lockdown since $24^{\text {th }}$ March 2020 , which was initiated with a voluntary public curfew on $22^{\text {nd }}$ March, followed by a 21-days lockdown starting from March $24^{\text {th }}$. Lockdown of the production sectors, restriction on human mobility, controlled public transportation system have resulted in the lowering of emission of pollutants. Along with the restriction measures to even out the epidemic curve but it has affected some other field. Studies by various scholars have shown how the lockdown has improved the ambient air quality, like in India(Gautam 2020; Mahato et al. 2020; Sikarwar and Rani 2020; Srivastava et al. 2020), U.S. (Berman and Ebisu 2020), Mexico (Méndez-Arriaga 2020), Kazakhstan (Kerimray et al. 2020), Iran (Abdul Halim et al. 2018),China(Fan et al. 2020; Zambrano-monserrate et al. 2020) especially in Wuhan (Cole et al. 2020; Lu et al. 2020; Sicard et al. 2020; Song et al. 2016; Q. Wang and Su 2020), Barcelona in Spain (Tobías et al. 2020), Sao-Paulo in Brazil (Nakada and Urban 2020), Milan in Italy (Collivignarelli et al. 2020), and Salé City in Morocco (Otmani et al. 2020) 
In India, air pollution has become a topic of intense debate at all levels mainly because of the enhanced anthropogenic activities e.g. rapid urbanization, higher population growth, increased energy consumption, and vehicular emission and industrial emission (Dadhich et al. 2018; Ghose et al. 2005; Gupta et al. 2008). Kolkata is the most polluted metropolis in India and suffers from the highest pollution levels among eight tropical Asian countries on the other hand Howrah is considered as one of the highly industrialized district in West (Mukherjee et al. 1998; Upadhyay et al. 2014; Financial Express 2020), This study aims to evaluate the changes in air quality in terms of pollutant concentration during the implementation of the lockdown measures considering COVID-19 pandemic in Kolkata and Howrah, the twin cities of West Bengal.

\section{Materials And Methods}

\subsection{Study Area:}

Kolkata at the eastern bank and Howrah at the western bank of Hooghly River are "the twin city" of West Bengal (Fig.1 The location of the study area). The "city of joy" Kolkata was also the capital of India during the British empire and Howrah is the adjacent main city (Debnath et al. 2018; Haque and Singh 2017). According to the 2001 census, Kolkata is the second-most populous city in India with a population of 1449669after Mumbai while the population of Howrah is $1,077,075$. Kolkata and Howrah rank $9^{\text {th }}$ and $30^{\text {th }}$ in world population ranking with a population density of 24252 persons/ sq. km and 20817 persons/ sq. km respectively (Census of India, 2011). The population of Kolkata and Howrah is ever increasing due to population growth and labour influx (Debnath et al. 2018).

The pollution level of Kolkata is close to Delhi and higher than that of Mumbai, and Chennai in India (Roy et al. 2015). It has also been known as "the dusty city" (Haque and Singh 2017). In 2018 World Health Organization (WHO) confirmed that Kolkata is the second-most polluted metropolis in the country, next only to Delhi. The study revealed another alarming trend that Kolkata's air quality is declining faster than that of Delhi. Kolkata and Howrah industrial belt are considered to be one of the highly industrialized districts in West Bengal where industries like engineering, casting, steel fabrication, shipbuilding, consumer goods industries, construction pressure die casting, forging, electric installations, manufacturing of industrial electrical goods accessories, etc. are highly concentrated (Upadhyay et al. 2014).Vehicular emissions from continuously increasing vehicles contribute a large in polluting air and the number has increased 8 times from 1951-2001(Chowdhury 2015).

The $\mathrm{PM}_{2.5}$ and $\mathrm{PM}_{10}$ are considered to be the main pollutants and have a constant concentration above the permissible level in Kolkata (Das et al. 2015). The northern part of Kolkata is mainly characterised by the residential areas, small scale industries, Cossipore thermal power station, and is surrounded by Hooghly River. The location of Dhapa dumping ground and east Kolkata wetland impacts the ambient air quality in the eastern part as well as the small scale industries and high traffic junctions in the central Kolkata pollute the air (Gupta et al. 2008).Due to densely distributed small scale industries without any pollution controlling measures, unplanned traffic flow and congestion Howrah city is to endure higher pollution of ambient air (Upadhyay et al. 2014). To assess the situation of air quality National Air Quality Monitoring Program initiated by the GOI in 1984 in India (CPCB, 2014). Air quality is monitored automatically at seven locations in Greater Kolkata and three locations in Howrah Municipal Corporation. Lockdown was imposed over the municipal corporations to bring down the infection from $24^{\text {th }}$ march by the GOI, 2020 and the change in air quality caused by lockdown has been analysed using the published air quality data from the concerned stations. So the study is mainly has focused on the changing air quality of the Kolkata Municipal Corporation (KMC) and Howrah Municipal Corporation (HMC).

\subsection{Data sources:}


To study the changes in air quality during the lockdown period, the data from ten monitoring sites in Kolkata Municipal Corporation (KMC), as well as in Howrah Municipal Corporation (HMC) (Table:1 Location of the monitoring stations) are taken into consideration. Monitoring station Bidhannagar is considered for spatial mapping purposes only for better understanding and excluded from all the statistical analysis because the eastern part is only covered by this station but does not come under KMC. The location of all these ten monitoring stations is shown in Fig. 1 (Fig. 1 Location of the study area). Data from $22^{\text {nd }}$ February2020, to $23^{\text {rd }}$ March 2020 (four-week before the lockdown) and from $24^{\text {th }}$ March 2020 to $3^{\text {rd }}$ May 2020 (tenure of complete lockdown) were used to calculate variations in concentrations and appraise the relative change from pre-lockdown period to the complete lockdown period.

The West Bengal Pollution Control Board (WBPCB), under the guidance of the National Air Quality Monitoring Program (NAMP), regularly monitors the ambient air quality of major urban towns and industrial areas of the state. The daily concentration of seven pollutants including particulate matter $\left(\mathrm{PM}_{2.5}\right.$ and $\left.\mathrm{PM}_{10}\right)$, nitrogen dioxides $\left(\mathrm{NO}_{2}\right)$, sulfur dioxide $\left(\mathrm{SO}_{2}\right)$, Ammonia $\left(\mathrm{NH}_{3}\right)$ on 24 hours interval on the other hand ozone $\left(\mathrm{O}_{3}\right)$ and carbon monoxide $(\mathrm{CO})$ have been taken into consideration on an 8 hours interval for air quality assessment from the Central Pollution Control Board online portal for air quality data dissemination (https://app.cpcbccr.com/ccr/\#/caaqm-dashboard-all/caaqm-landing) to give an inclusive analysis of the air quality data under the national ambient air quality standards. . In the AQI system PM2.5, $\mathrm{PM}_{10}, \mathrm{NO}_{2}, \mathrm{SO}_{2}, \mathrm{NH}_{3}, \mathrm{CO}, \mathrm{O}_{3}$ and $\mathrm{Pb}$ but here $\mathrm{Pb}$ is excluded because the concentration of this pollutant is not available at real-time and cannot be taken into consideration for real-time AQI calculation (CPCB, 2014). These data are also verified from different sources like AQI-India(https://app.cpcbccr.com/AQI_India/) under the Central Pollution Control Board, WBPCB (http://emis.wbpcb.gov.in/airquality/JSP/aq/districtwiseReport.jsp) under West Bengal Pollution Control Board and OpenAqportal (https://openaq.org/\#/location/Arya\%20Nagar,\%20Bahadurgarh\%20-\%20HSPCB?_k=cpmf34).

Concentrations of $\mathrm{NO}_{2}$ (0.25。 level-3 (L3) daily OMI tropospheric) for the period of $22^{\text {nd }}$ February to $3^{\text {rd }}$ May of 2019 and 2020 were acquired from Giovanni interface (http://giovanni.gsfc.nasa.gov/giovanni/), derived from the NASA Goddard EarthSciences Data Active Archive Center (GES DISC; http://disc.sci.gsfc.nasa.gov).

\subsection{Data Analysis}

The air quality index (AQI) is a measure of the cumulative effect of individual pollutants concentration on the quality of air in different places but the modification of the method which is termed as National Air Qulaity Index (NAQI) is based on maximum operator approach to avoid the uncertainty (CPCB 2014; Dadhich et al. 2018; Joshi and Mahadev 2011; Mahato et al. 2020). Central pollution control board (CPCB), India monitors the ambient air continuously and has been using the EPA-US method to calculate the Air quality indices (AQI) (Chaurasia et al., 2013; Kumar \& Dash, 2018). Here we only briefly summarized it. Calculation of Sub-indices for each and individual pollutant and then the aggregation of breakpoint values (sub-indices), which depend upon the Indian National Ambient Air Quality Standards (NAAQS) are the two steps involved in AQI calculation. The Maximum value of the sub-indices is taken as the AQI. The AQI standards are displayed in number form that describes the Quality rating (potential health effects) as shown in Table:2 (Table:2 Proposed Breakpoints for AQI Scale 0-500).

As the study is carried out in KMC and HMC, the municipal ward boundary map is designed in a GIS environment. ArcGIS 10.3, distributed by the Environmental Systems Research Institute (ESRI), has been employed for spatial analysis to identify air pollution levels. Based on the ten monitoring sites; the interpolated maps of each pollutant and AQI have been generated from pre-lockdown tenure to during lockdown tenure. In this study, Inverse Distance Weighting (IDW) interpolator by linear combination model has been used because it is easy to operate than others without any preprogram assumptions to opt for a semi-variogram model (Jumaah et al. 2019; Poshtmasari et al. 2012) 
ANOVA (Two-way), Cluster Analysis (single linkage) based on the Euclidean distance and Ward's methods and Pearson Moment Correlation Coefficient ( $r$ ) were computed using IBM SPSS version23. STATA 12 was used for the Box plots of AQI. The ANOVA helps to understand the variation in Air Quality Index in each location as well as in pre-lockdown and during lockdown tenure while correlation analysis denotes the degree of association among the different pollutants is done using JMP 15.Box plots are especially valid for comparing two or more distribution and also present a graphical display based on the order-statistic summaries of median and quartiles. Tables and charts have been used to report descriptive statistics by calculating the simple percentage, tabulation, and cross-tabulation. Using MS Excel line graphs for each pollutant are graphically represented.

\section{Results And Discussion}

\subsection{Observed concentration of the air pollutants:}

The concentration of the pollutants in the study area is summarised (Table:3 Summary statistics of atmospheric pollutants concentration in Kolkata and Howrah Municipal Corporation, 2020) to understand the change in maximumminimum concentration and mean concentration of the pollutants, for all the concerned recording stations of the 'twin city' for the pre-lockdown (PL) period from $22^{\text {nd }}$ February to $21^{\text {st }}$ March and the during lockdown (DL) period from $24^{\text {th }}$ March to $3^{\text {rd }}$ May, 2020. For all the stations a sharp reduction has been noted in the concentration of $\mathrm{PM}_{2.5}$ and $\mathrm{PM}_{10}$ from the pre-lockdown to during lockdown. The highest concentration with an amount of $149.68 \mu \mathrm{g} / \mathrm{m}^{3}$ has been monitored at Ballygunge for $\mathrm{PM}_{2.5}$ in Kolkata whereas Gusuri $333.52 \mu \mathrm{g} / \mathrm{m}^{3}$ for $\mathrm{PM}_{10}$ in Howrah at 24 hours interval. In the pre-lockdown tenure, the monitored amount of $\mathrm{PM}_{2.5}$ is above the level of the AQI standards because of intensive industrial belts such as paper pulp, chemical industries, textile, rubber, iron, etc. as well as high traffic congestion and emission from the thermal power plants which are associated with the corresponding stations (Spiroska et al. 2013). The mean concentration has been reduced from 78.8 during pre-lockdown to 25.4 during the lockdown phase. The reduction of 2.75 times of $\mathrm{PM}_{10}$ at Ghusuri, alongside the mean difference between the pre-lockdown to during lockdown, is $125.4 \mu \mathrm{g} / \mathrm{m}^{3}$ is below the AQI standard. On the other hand, minimum concentration has been recorded at Belur Math with a mean concentration of $41.57\left(\mu \mathrm{g} / \mathrm{m}^{3}\right)$ after the imposition of lockdown. The complete lockdown has reduced the power consumption, traffic congestion, and emission from the production units to a very minimal level. The highest concentration is found at Ghusuri and the lowest at Belur Math, HMC during the previous phase of lockdown.

Severe degradation of air quality is also caused by $\mathrm{NO}_{2}$. It is emitted from both the natural sources of nitrogen cycle by the process of biological processes, lighting effect and the anthropogenic sources as vehicular emission from the highly congested traffic flow (Ibe et al. 2020). During weekends average traffic flow is $2.3 \times 10^{4}$ and it is raised to $2.8 \times 10^{4}$ duringweekdays near industrial centres in Kolkata (Gupta et al. 2008). The highest concentration $(97.42 \mu \mathrm{g} / \mathrm{m3})$ of NO 2 has been recorded at Belur Math in HMC, ranging from 32.4-97.42 $\mu \mathrm{g} / \mathrm{m}^{3}$ but the range is lowered to $11.19-29.11 \mu \mathrm{g} / \mathrm{m3}$, a reduction of 3.24 times during lockdown from pre-lockdown phase. The minimum value is recorded during the lockdown period at Padmapukur, HMC. During the complete-lockdown period, Belur Math has recorded the highest concentration and followed by Victoria, Fort William, Ghusuri, RabindraBharati, Padmapukur, Jadavpur, Ballygunge and RabindraSarovar. The stations can be arranged according to mean concentration as RabindraBharati>BelurMath>Ghusuri>Victoria $>$ Fort William $>$ Padmapukur>Jadavpur $>$ RabindraSarovar $>$ Ballygunge in prelockdown phase. $\mathrm{SO}_{2}$ as an atmospheric gas is released when coal is burnt, decaying of grassland or vegetation, volcanoes and ocean. It is a precursor of acid rain in the form of Sulphuric acid $\left(\mathrm{H}_{2} \mathrm{SO}_{4}\right)$, deposits in the surface and subsurface, and also in oxidized form as sulfate having a dominating role in "radiative forcing" of climate (Cox 2003; T. Wang et al. 2006). $67.32 \mu \mathrm{g} / \mathrm{m}^{3}$ is the highest recorded concentration of $\mathrm{SO}_{2}$ at Ghusuri of HMC, ranging from 16.02$67.32 \mu \mathrm{g} / \mathrm{m}^{3}$ in the pre lockdown period and has reduced to $5.73-17.78 \mu \mathrm{g} / \mathrm{m}^{3}$ during the lockdown period. A four-time 
reduction of mean concentration is noted from pre-lockdown to during lockdown period at Ghusuri in HMC. Based on the mean concentration of the pre-lockdown period the stations can orderly be arranged as Ghusuri>Belur Math $>$ RabindraBharati $>$ RabindraSarovar $>$ Victoria $>$ Padmapukur $>$ FortWilliam $>$ Ballygunge $>$ Jadavpur and during the lockdown period, Belur Moth>RabindraBharati>Padmapukur>Victoria $>$ Ghusuri $>$ Jadavpur $>$ RabindraSarovar $>$ Fort William>Balygunj. Ghauri, Belur Math, Ballygunge, and RabindraSarovar have noted significant scaling down but all the other stations have recorded very minimal change. This can be because of the continuation of coal-burning for power supply for the whole area with a decreasing consumption due to lockdown. Ozone is produced and directly emitted because of reactions between nitrogen Dioxide (primary pollutant) and certain organic compounds mixed in the air under the influence of ultraviolet rays (Arbilla et al., 2002). Due to the unavailability of the data at Belur Math, the station is not considered for discussion. Victoria and its adjoining areas are prominent for the concentration of $\mathrm{O}_{3}$, which varies from 10.1 to $92.60 \mu \mathrm{g} / \mathrm{m}^{3}$ in the pre-lockdown period but the concentration has hiked to $24.02-108.53 \mu \mathrm{g} / \mathrm{m}^{3}$ in the during lockdown period. Ozone concentration has been hiked because Ozone can be degraded and regenerated by $\mathrm{NO}_{\mathrm{x}}$ and more degradation is associated with urban areas where local scale ozone depletion is found near high $\mathrm{NO}_{\mathrm{x}}$ emitting zone and the magnitude is determined bythe ratio of $\mathrm{NO}_{2}$ and $\mathrm{NO}$ (Arbilla et al. 2002). During the lockdown period, the emission of $\mathrm{NO}_{2}$ is reduced and has limited the degeneration process of ozone, results in continuous hiking of ozone in the atmosphere. The spatial concentration pattern of ozone can be represented as Victoria $>$ Ballygunge $>$ RabindraSarovar $>$ FortWilliam $>$ Padmapukur>RabindraBharati>Jadavpur $>$ Ghusuri in the prelockdown phase and Victoria>Ballygunge>RabindraSarovar>Padmapukur>Fort William>RabindraBharati>Jadavpur>Ghusuri during lockdown phase. $\mathrm{CO}$ is a trace gas, emitted due to incomplete combustion of fossil fuel and reaction among oxidation of hydrocarbons, volatile organic compounds and methane, also from the vehicle, industrial hubs and wood fires(Aneja et al. 2001; Gaur et al. 2014; Njoku et al. 2016). National Green Tribunal (2019) reported that street food stalls on footpaths use charcoal, dump cake and other materials as fuel are the sources of severe pollution. Victoria has recorded the highest concentration of CO that ranges from $0.44-2.28 \mathrm{mg} / \mathrm{m}^{3} \mathrm{in}$ the pre-lockdown phase and is reduced to $0.44-1.77 \mathrm{mg} / \mathrm{m} 3$. During the pre-lockdown-phase, the highest concentration is found at Victoria and the minimum concentrated zone of $\mathrm{CO}$ is Rabindra Bharati and the recorded spatial concentration pattern during the lockdown phase is Victoria>Padmapukur>Jadavpur>Ghusuri>Belur Math>Rabindra Sarovar>Ballygunge>Fort William=Rabindra Bharati during the lockdown-phase. $\mathrm{NH}_{3}$ is an alkynes gas, emitted from both the anthropogenic processes (animal waste, fertilizer; waste management; vehicular emission, incomplete burning of home-cooking fuel and dumping stations) and atmospheric processes (Fenn et al. 2018). In Kolkata, a high concentration of $\mathrm{NH}_{3}$ can be traced out where the land use pattern is dominated by industrial, commercial, and residential areas. The residential areas are associated with dumping stations so these residential parts also have a high concentration of $\mathrm{NH}_{3}$ (Gupta et al. 2008). During the pre-lockdown phase, $\mathrm{NH}_{3}$ has taken the highest concentration at Jadavpur. The engrossment ranges from $15.07-79.76 \mu \mathrm{g} / \mathrm{m}^{3}$ to $5.81-15.04 \mu \mathrm{g} / \mathrm{m}^{3}$ in the during lockdown phase. The mean concentration has dropped from 26.6 to $9.1 \mu \mathrm{g} / \mathrm{m3}$, almost a three times reduction from the pre-lockdown to during lockdown. The orderly arrangement during PL can be noted as Rabindra Bharati>Belur Math $>$ Jadavpur $>$ Victoria $>$ Padmapukur $>$ FortWilliam $>$ Ghusuri $>$ Ballygunge $>$ RabindraSarovarandduring lockdown period, Rabindra Bharati> Victoria>Rabindra Sarovar>Belur Math>Ghusuri> Fort William= Jadavpur>Padmapukur.

Line graphs (Fig. 224 hours mean concentrations of (a) PM2.5, (b) PM10, (c) NO2, (d) $\mathrm{NH}_{3}$ (e) SO 2 (h) AQI and 8 hours mean concentrations of (e) CO \& (f) 03 between $22^{\text {nd }}$ February to $3^{\text {rd }}$ May, 2020 in Kolkata and Howrah) have been drawn based on pollutant concentration data for all the stations in KMC and HMC then are averaged and then plotted. It represents the nature of the concentration of the pollutants. $\mathrm{NO}_{2}, \mathrm{SO}_{2}, \mathrm{CO}, \mathrm{O}_{3}, \mathrm{NH}_{3}$ have been recorded at a satisfactory level but it has been noted that $\mathrm{PM}_{2.5}$ and $\mathrm{PM}_{10}$ are above the satisfactory level in the pre-lockdown phase and can be considered as the main pollutants in both $\mathrm{KMC}$ and $\mathrm{HMC}$. But during the lockdown phase, the concentration has been reduced to a satisfactory level for all the pollutants except $\mathrm{O}_{3}$. The main scaling down can be noted for $\mathrm{PM}_{2.5}$ and $\mathrm{PM}_{10}$ 
from the pre-lockdown to the complete lockdown period. AQI is the combined form of all the pollutants is also showing that during the lockdown period the air quality has improved to the 'good' category.

The box plots (Fig. 3 Box plot comparing AQI distribution for nine monitoring stations between pre-lockdown and during lockdown phase) of all stations are depicting the change in AQI from pre-lockdown to during-lockdown. In pre-lockdown tenure, the station Ballygunge in Kolkata Municipal Corporation has been noted for 'poor' air quality as prescribed by CPCB, 2014 (Table:2 Proposed Breakpoints for AQI Scale 0-500) because of the nearby polluting sites.

Most of the stations have recorded god to satisfactory air quality during lockdown period in both the municipal corporations. At Ballygunge where the highest AQI value during pre-lockdown has been calculated as well as the median of the distribution or $\mathrm{Q}_{2}$ is reduced from 163.67 to 58.29 , a three times reduction from the pre-lockdown to duringLockdown. From the diagram (Fig. 3 Box plot comparing AQI distribution for nine monitoring stations between prelockdown and duringlockdown phase), the major polluted stations are Ballygunge, RabindraBharati University and Ghususri. The lowest AQI has been recorded during the lockdown period at Belur Math in Howrah Municipal Corporation.

\subsection{Cluster Analysis:}

Cluster analysis is a multivariate analysis that has been used to determine the grouping pattern of the monitoring stations in the pre-lockdown and during the lockdown phase based on AQI (Fig.4 Cluster analysis of the stations in the (a) pre-lockdown (b)during lockdown period). Euclidean distance and Ward's methods were employed to measure the distance among stations (David et al. 2019).

In the pre-lockdown phase the stations Jadavpur, Rabindra Sarovar, Fort William and Victoria located in the central part of the study area, are in the 1st cluster (Fig. 4a Cluster analysis of the stations in the pre-lockdown). The AQI is similar for these stations Rabindra Bharati, Ghusuri, Ballygunge, Padmapukur and have made a cluster because Ghusuri and RBU are affected by the nearby Cossipore thermal power station whereas Ballygunge is located amongst the local small scale industries in KMC and Padmapukur is also affected by small scale industries in HMC. During the lockdown period, the clustering patterns (Fig. 4b Cluster analysis of the stations in the during lockdown) have changed. Fort William, Rabindra Bharati University, Victoria, and Ghusuri have made a cluster and the rest of the stations have made the other clusters.

\subsection{Spatial Distribution of Pollutants:}

The cluster analysis has shown the pattern of cluster of the stations based on the AQI. Spatial variability has been represented in the form of spatio-temporal map for the pollutants and the AQI from the pre-lockdown phase to during lockdown phase for few selected days. The variability is represented based on the pollutants for each of the stations. Different factors like Vehicular emission is a most important factor for Kolkata and the decennial growth of vehicle is like two-wheelers almost 70\% followed by four-wheelers (20\%), three-wheeler (10-14\%) and bus (8-13\%) and the high traffic flow junctions are Park Circus even point junction, B.B.D Bag, Gariahat, Rashbehari, Ballygunge, M.G Road (Chowdhury 2015). Kolkata-Howrah industrial belt is another important source of pollution. Howrah is known for its intense small scale industries (Upadhyay et al., 2014). The main sites of industrial pollution are Pyarabagan, Garden Reach, Taratala, Mallickbazar, Dhapa, Cossipore thermal power station (Datta et al. 2016).

In 2019 most of the study area as well as India was covered with higher values of particulate matter, which are showing in red colour in the map (Fig. 5a Change in concentration from $1^{\text {st }}$ April, 2019 to 2020 of $\mathrm{PM}_{2.5}$ ). While in 2020 on the same date the concentration of particulate matter in the atmosphere is considerably much lesser than the previous year(Fig. 5b Change in concentration from $1^{\text {st }}$ April, 2019 to 2020 of $\mathrm{PM}_{10}$ ), due to restricted emission from vehicles, construction sites and factories during complete lockdown tenure. 
24hours Timely Averaged Map of $\mathrm{NO}_{2}$ (1/cm2) from 24 ${ }^{\text {th }}$ March to $3^{\text {rd }}$ May, 2019 (Fig. 6a 24hours Timely Averaged Map of $\mathrm{NO}_{2}(1 / \mathrm{cm} 2)$ from $24^{\text {th }}$ March to $3^{\text {rd }}$ May, 2019) from the NASA Giovanni and concentration from $24^{\text {th }}$ March to $3^{\text {rd }}$ May 2020 (Fig. 6b 24hours Timely Averaged Map of $\mathrm{NO}_{2}$ (1/cm2) from $24^{\text {th }}$ March to $3^{\text {rd }}$ May, 2020), the tenure of the complete of lockdown in India are compared. Here a significant reduction has seen in the concentrationNO $\mathrm{N}_{2}$ over $\mathrm{Kolkata}$ and Howrah as well as West Bengal as compared to the same phase of the previous year.

To show the spatial variability of pollutants in the pre-lockdown and during lockdown phase in particularly Kolkata and Howrah Municipal Corporation, $1^{\text {st }}$ March and $13^{\text {th }}$ March during the pre-lockdown span, $24^{\text {th }}$ March, the day when lockdown started; $7^{\text {th }}$ April and $3^{\text {rd }}$ May during lockdown are chosen. The day of Janta Curfew played an important role in bringing down the pollution level in Kolkata and Howrah Municipal Corporation.

$\mathrm{PM}_{2.5}$ (Fig. 7 Spatio- temporal change of $\mathrm{PM}_{2.5}, 2020$ ) and $\mathrm{PM}_{10}$ (Fig. 8 Spatio- temporal change of $\left.\mathrm{PM}_{10}, 2020\right)$ are the two most important pollutants in Kolkata and Howrah (Das et al. 2015). A high concentration of $\mathrm{PM}_{2.5}$ is recorded especially near Ghusuri, Howrah (Fig. 7 Spatio- temporal change of $\mathrm{PM}_{2.5}, 2020$ ). Another two most important concentration zones can be found near RBU due to its stone-throwing distance to Cossipore power station as the main source of $\mathrm{PM}_{2.5}$ and $\mathrm{PM}_{10}$ andanother is near Ballygunge asthis part is surrounded by nearby industrial centreslike Mullick Bazar, Picnic Garden, Topsia and Kasba(Das et al. 2015). On 13 ${ }^{\text {th }}$ March the reduction in concentration can be noticed, only at Ghusuri and Victoria medium concentration is recorded. On $24^{\text {th }}$ March the concentration has flattened due to the Janta Curfew on $22^{\text {nd }}$ March, shutting down of the industries, reduction in traffic flow, shutting down of street cooking shops, and reduction in power consumption(The Economics Times 2020). On the $7^{\text {th }}$ April, a slight increase can be noted then again a fall in concentration is reported. Ghusuri recorded medium concentration also during the lockdown period. So this part has a constant emission of $\mathrm{PM}_{2.5}$. The pattern of concentration of $\mathrm{PM}_{10}$ is the same as $\mathrm{PM}_{2.5}$, it may be because of almost the same sources of emission (Ibe et al. 2020).

Prominent $\mathrm{NO}_{2}$ emitting zones (Fig. 9 Spatio- temporal change of $\mathrm{NO}_{2}, 2020$ ) are found atBelur Math, Rabindra Bharati, in the northern part and Fort William and Victoriain the central part. Zones of medium concentration are found in the extreme western Kolkata, limited areas of central Kolkata, and the eastern part of Kolkata due to high traffic flow (Gupta et al. 2008). From $13^{\text {th }}$ march before lockdown a slight reduction can be seen (Fig. 9 Spatio- temporal change of $\mathrm{NO}_{2}$, 2020) due to less traffic flow in Kolkata, a moderate concentration is reported but near Ballygaunj and Belur Math. On the day of $24^{\text {th }}$ March, the concentration was scaled down due to Janta Curfew on $22^{\text {nd }}$ march that can be a probable factor, and after $24^{\text {th }}$ March concentration pattern is almost the same for all the stations.

The major concentration of $\mathrm{NH}_{3}$ (Fig. 10 Spatio- temporal change of $\mathrm{NH}_{3}, 2020$ ) is identified near RBU and Belur Math. The $\mathrm{NH}_{3}$ concentration at Kosba is high because of animal wastes, livestock, and fertilizer (Carmichael et al. 2003). Nearby solid waste dumping stations are responsible for high $\mathrm{NH}_{3}$ emission near residential areas with higher vehicular emissions due to catalytic conversion of petrol vehicles $\mathrm{NH}_{3}$ is generated (Gupta et al. 2008). Dhapa solid waste dumping station in the east margin of Kolkata is responsible for higher $\mathrm{NH}_{3}$ emission. All the probable sources were active during the pre-lockdown phase but emission started reducing after the Janta Curfew and during the countrywide lockdown.

Small scale industries in Howrah accelerate pollution level and are responsible for high $\mathrm{SO}_{2}$ concentration (Fig. 11Spatiotemporal change of $\mathrm{SO}_{2}, 2020$ ). The southern part has very minimum emission but the northern, central and northwestern parts have recorded higher $\mathrm{SO}_{2}$ emission on $1^{\text {st }}$ March. Concentration is moderately distributed in the northern part near Belur Math, $\mathrm{RBU}$ and Ghusuri but all the parts have a sharp reduction in $\mathrm{SO}_{2}$ emission on $13^{\text {th }}$ March 
(Fig. 11Spatio- temporal change of $\left.\mathrm{SO}_{2}, 2020\right)$. On $24^{\text {th }}$ March and 7th April, only areas near Belur Math and marginal eastern parts are recorded moderate $\mathrm{SO}_{2}$ emission and on $3^{\text {rd }}$ May the $\mathrm{SO}_{2}$ emission has been flattened all over the study area.

The concentration of $\mathrm{CO}$ is monitored on 8hrs interval. Medium to high $\mathrm{CO}$ concentrations has been observed in KMC and HMC (Fig. 12Spatio- temporal change of CO 2020) due to high vehicular emission and burning of woods, fossil fuel for cooking in residential areas and street-side shops. The $\mathrm{CO}$ is released mainly from Kasba, Picnic Garden, Mullick Bazar, Topsia are known for industrial activities that affect the neighboring stations which are Victoria, FortWilliam, and Ballygunge(Datta et al. 2016). From $24^{\text {th }}$ March, the day of lockdown, a mark reduction in CO concentration is noticed but a centre with relatively higher concentration is found near Ballygunge and later no such considerable changes are observed.

Spatial Pattern of ozone concentration is different from the other pollutants (Fig. 13Spatio- temporal change of $\mathrm{O}_{3}$, 2020). The concentration has increased till $7^{\text {th }}$ April. Ozone concentration is inversely related to $\mathrm{NH}_{3}$ and $\mathrm{NO}_{2}$, which is the reason for relatively lower concentration during the pre-lockdown phase and it can also be found from the correlation matrix (Fig.15Correlation among the pollutants during the (a) pre-lockdown and (b) during the lockdown period). It is important to note that hiking of $\mathrm{O}_{3}$ is caused by lower titration of $\mathrm{O}_{3}$ by $\mathrm{NO}$ due to the minimum emission of NOx from the vehicle (Sicard et al. 2020). The high concentration of $\mathrm{NO}_{2}$ can be noticed in the map (Fig. 10Spatio- temporal change of $\mathrm{NH}_{3}$, where central Kolkata with its adjoining stations Ballygunge, Fort William and Victoria are important for high $\mathrm{NO}_{2}$ emission due to both industrial and vehicular emission and an opposite scenario can be observed for ozone concentration because ground-level ozone depletion zones are adjoined with high $\mathrm{NO}_{2}$ emitting zones (Rahmadi \& Kim, 2014; Upadhyay et al., 2014). The same phenomena can be observed in the northern part at Rabindra Bharati University near Cossipore thermal power station where higher $\mathrm{NO}_{2}$ concentration with lower ozone concentration is reported. $13^{\text {th }}$ march has a relatively lower concentration and after the day $\mathrm{O}_{3}$ concentration has increased till $7^{\text {th }}$ April and again a fall in concentration is recorded.

AQI has fallen to 25 on 3rd May from 325 on 1st march. In the map (Fig. 14 Showing the spatio-temporal variation of $\mathrm{AQI})$ showing that the higher concentration of the pollutants in the atmosphere is responsible for higher AQI and the opposite scenario can be observed during the lockdown period. Adjoining areas of Rabindra Bharati University, Ghusuri, Padmapukur, Ballygunge, Jadavpur, and RabindraSarovar come under poor air quality index. A slight reduction in AQI and can be categorized under 'moderately polluted' on 13th March. On 24th March air quality is improved to 'good' but a slight degradation can be observed on 7th April and then again the air quality has remarkably improved.

\subsection{Co-relationship between the ambient air pollutants:}

To analyze the association among the pollutants, multiple correlation matrixes are conducted for pre lockdown and during the lockdown phase (Fig. 15 Correlation among the pollutants during the (a) pre-lockdown and (b) during the lockdown period).

$\mathrm{PM}_{2.5}$ has a strong significant relationship with $\mathrm{PM}_{10}(\mathrm{r}=0.99 *)$, this may be the result of almost same sources of emission as previously discussed in pre-lockdown phase but later the correlation is also significant ( $\left.r=0.92^{\star}\right)$ (Ibe et al., 2020).Due to the reduction of traffic congestion, the lockdown of industrial areas the emission of these particulates also is reduced with $\mathrm{NO}_{2}$ and $\mathrm{CO}$, a strong correlation has been found with $\mathrm{PM}_{2.5}$ because both the correlated pollutants are highly recorded near highly intensified traffic flow junction and industrial belts. During the lockdown period, the relation among the parameters has drastically changed as the relationship has taken a new dimension when there is a mark reduction in pollutant concentration. Almost the same phenomena can be observed for $\mathrm{PM}_{10}$ and these two particulate 
matters are the major source of pollution in Kolkata (Das et al. 2015). Significantly moderate correlations have been traced out between $\mathrm{NH}_{3}$ and $\mathrm{NO}_{2}, \mathrm{PM}_{2.5}, \mathrm{PM}_{10}$, except these all the relations are insignificant in the pre-lockdown phase. But the correlations have become significant in the during lockdown phase. $\mathrm{NH}_{3}$ has positive significant correlations with $\mathrm{PM}_{2.5}\left(\mathrm{r}=0.87^{\star}\right), \mathrm{PM}_{10}\left(\mathrm{r}=0.80^{\star}\right), \mathrm{SO}_{2}(\mathrm{r}=0.79 *), \mathrm{CO}\left(\mathrm{r}=0.85^{\star}\right)$ and $\mathrm{O}_{3}\left(\mathrm{r}=0.73^{*}\right)$.

Sulfur dioxide is the precursor of acid rain as Sulphuric acid in reaction with $\mathrm{H}_{2} \mathrm{O}$. Any significant correlation has not established with $\mathrm{SO}_{2}$ with other pollutants except a significant negative correlation $(\mathrm{r}=-0.31)$ with $\mathrm{NH}_{3}$. According to chemists, any chemical reaction is not possible between these two pollutants except water (Guo et al., 2005). But the total scenario of $\mathrm{SO}_{2}$ has been changed during the lockdown period when there is a dropping down of pollutants concentration that results in the establishment of significant correlation with $\mathrm{PM}_{2.5}\left(r=0.73^{\star}\right), \mathrm{PM}_{10}\left(r=0.67^{\star}\right), \mathrm{NH}_{3}$ $\left(\mathrm{r}=0.79^{*}\right), \mathrm{CO}\left(\mathrm{r}=0.61^{*}\right)$ and $\mathrm{O}_{3}\left(\mathrm{r}=0.73^{*}\right)$. A moderately significant correlation $\left(\mathrm{r}=0.54^{*}\right)$ has been found between $\mathrm{SO}_{2}$ and ozone. The PL phase is characterised by higher SO2concentration and relatively less concentration of Ozone. Higher $\mathrm{SO}_{2}$ concentration accelerates Ozone formation because of its role in the photochemical reaction that produces ozone in combination with NOx, VOC when insolation is higher. In the during lockdown phase, a highly significant positive correlation $\left(r=0.73^{\star}\right)$ has been found between these two components.

$\mathrm{CO}$ is only strongly correlated with $\mathrm{PM}_{2.5}\left(r=0.73^{\star}\right), \mathrm{PM}_{10}\left(r=0.75^{\star}\right)$, and $\mathrm{NO}_{2}\left(r=0.77^{\star}\right)$ in the pre-lockdown phase but during the lockdown phase the relations have also established with other pollutants. The main sources of $\mathrm{CO}$ are the partial combustion of fossil fuel, vehicular emission related to highways, incursion from industries, power plants these areas are also related to the addition of $\mathrm{PM}_{2.5}$ and $\mathrm{PM}_{10}$ in the atmosphere, as a result, a significant relationship has been found.

In pre-lockdown phase $\mathrm{NH}_{3}$ and $\mathrm{O}_{3}$ hada significantly negative correlation $\left(\mathrm{r}=-0.64^{\star}\right)$ where the concentration of both the pollutants was high. Olszyna and Heicklen (1972), showed in an experiment that $\mathrm{O}_{3}$ is consumed and solid aerosol is formed in reaction with $\mathrm{NH}_{3}$ rapidly but it not reproducible. A high concentration of $\mathrm{NH}_{3}$ in the pre-lockdown phase and chemical reaction in the atmosphere reduces the amount of Ozone. On the other hand, during the lockdown period the correlation has a significant positive correlation $\left(r=0.72^{*}\right)$ because the reaction is not possible when the amount is not significant (Olszyna, \& Heicklen, 1972). Ozone is also negatively correlated with $\mathrm{NO}_{2}$. The reactions between these two components result in the degeneration and regeneration of ozone. The high incursion of $\mathrm{NO}_{2}$ from the vehicle and industrial areas degrade Ozone in the atmosphere by chemical reactions (Cox, 2003). $\mathrm{NO}_{2}$ is broken down into $\mathrm{NO}$ that reacts with $\mathrm{O}_{3}$ in the presence of $\mathrm{UV}$, then again NO reacts with $\mathrm{O}_{3}$ and $\mathrm{NO}_{2}$ and $\mathrm{O}_{2}$ are the outcomes (Ebi and McGregor 2008). Coldbeck \& Harrison, 1982 explained the relationship "If formaldehyde is photolysed, then

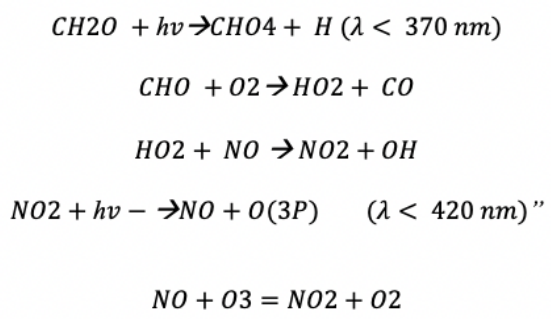

The whole process continues all the time. This phenomenon is normal during the weekdays but during weekends $\mathrm{NO}_{2}$ concentration is reduced and $\mathrm{O}_{3}$ is increased in the atmosphere likewise lockdown phase. A study by Cox (2003), showed that the area of ozone depletion is highly associated with $\mathrm{NO}_{2}$ emitting areas. From the Figure (Fig. 15 Correlation among the pollutants during the (a) pre-lockdown and (b) during the lockdown period), it can be noticed that the relation 
between two pollutants turned into a significant positive correlation $\left(r=0.60^{\star}\right)$ from a less significant negative correlation $(r=-0.15 *)$ in the pre-lockdown phase.

\subsection{Analysis of variance (ANOVA):}

Anova Two-Way has been used to understand the variance of means of Air Quality Index AQI for all the stations (9) of both Kolkata and Howrah (Table:4 Two-way ANOVA test for AQI based on stations and time). AQI is considered as the dependent variable and the period of pre-lockdown and during lockdown as the independent variables. After performing Anova Two-way it has been found that period (from pre-lockdown to during lockdown phase) has a very important role in reducing AQI, $F(1,611))=465.723, p<0.0001$ is a highly significant factor for the changing AQI. In changing AQI, time has a $43.9 \%$ impact alongwith the stations have $16.3 \%$ impact. If the time is constant then the station is also significant and the interaction effect is significant at 0.0001 level with $F(8,611)=14.440, p<0.0001$. The effect of interaction on the AQI is also found significant $F(8,611)=6.045, p<0.0001$. The Table:4 (Table:4 Two-way ANOVA test for AQI based on stations and time) is showing the pairwise comparisons within the station of AQI from the pre-lockdown phase to during the lockdown phase and the table:4 (Table:4 Two-way ANOVA test for AQI based on stations and time) showing that the mean difference within the station is highly significant with $p<0.0001$ of all the stations. Station Ballygunge, Kolkata recorded the highest mean of 108.194 at $p<0.0001$ significant level between before lockdown and during lockdown period, on the other hand, Rabindra Sarovar, Kolkata recorded minimum mean difference of 45.735 with a significant level $p<0.0001$. The estimated mean differences of AQI between the lockdown period and pre-lockdown period are considerable for all the stations (Fig. 16 Mean difference of each station between the pre-lockdown and duringlockdown). The air quality was 'poor' at Ballygunge, Rabindra Bharati University and Ghusuri but the air quality has remarkably improved in the lockdown period.

\section{Conclusion}

The study has been yielded with a significant outcome that the lockdown has remarkably reduced the pollution level and air quality has improved from the 'poor' category to the 'good' category from the pre-lockdown period to during lockdown period in KMC and HMC. The major three pollution sites are Ballygunge and RBU in KMC and Ghusuri in HMC where the "poor" AQI has been calculated. The major pollutants are $\mathrm{PM}_{2.5}, \mathrm{PM}_{10}$ and $\mathrm{NO}_{2}$ and have markedly condensed from prelockdown to during lockdown period. The Cossipore thermal power station, small scale industrial hubs and traffic are the main sources of pollution but the imposition of lockdown all over the country has resulted in a quick fall in the concentration of pollutants. Implementations of lockdown at this temporal and regional scale are not possible but the situation has proved that the recovery of the environment is very rapid when human interventions are very less.

\section{Declarations}

\section{Conflict of interest}

The authors have no conflict of interests.

\section{Acknowledgement}

The authors acknowledge the NASA Giovanni and Earth nullschoolfor the free use of pollutants data and map. We acknowledge the CPCB online portal to provide the data free of cost. We are thankful to Aparupa Sinha, Susmita Ghosh and Sukanya Das for their immense contribution in improving the literature. We also want to express our sincere gratitude to the anonymous reviews and editors for their comments which contributed to the improvement of the paper.

\section{References}


Abdul Halim, N. D., Latif, M. T., Ahamad, F., Dominick, D., Chung, J. X., Juneng, L., \& Khan, M. F. (2018). The long-term assessment of air quality on an island in Malaysia. Heliyon, 4(12). https://doi.org/10.1016/j.heliyon.2018.e01054

Aneja, V. P., Agarwal, A., Roelle, P. A., Phillips, S. B., Tong, Q., Watkins, N., \& Yablonsky, R. (2001). Measurements and analysis of criteria pollutants in New Delhi, India. Environment International, 27(1), 35-42.

https://doi.org/10.1016/S0160-4120(01)00051-4

Arbilla, G., Martins, E. M., Moreira, A., \& Moreira, L. F. R. (2002). Ozone air quality modeling. A case study: A heavily vehicle impacted urban avenue in Rio de Janeiro, Brazil. Journal of the Brazilian Chemical Society, 13(3), 308-317. https://doi.org/10.1590/S0103-50532002000300004

Berman, J. D., \& Ebisu, K. (2020). Changes in U.S. air pollution during the COVID-19 pandemic. The Science of the total environment, 739, 139864. https://doi.org/10.1016/j.scitotenv.2020.139864

Carmichael, G. R., Ferm, M., Thongboonchoo, N., Woo, J. H., Chan, L. Y., Murano, K., et al. (2003). Measurements of sulfur dioxide, ozone and ammonia concentrations in Asia, Africa, and South America using passive samplers. Atmospheric Environment, 37(9-10), 1293-1308. https://doi.org/10.1016/S1352-2310(02)01009-9

Census of India 2011 WEST BENGAL SERIES-20 PART XII-B DISTRICT CENSUS HANDBOOK KOLKATA VILLAGE AND TOWN WISE PRIMARY CENSUS ABSTRACT (PCA) DIRECTORATE OF CENSUS OPERATIONS WEST BENGAL. (2011).

Chowdhury, I. R. (2015). Scenario of vehicular emissions and its effect on human health in Kolkata city. International Journal of Humanities and Social Science Invention, 4(5), 1-9. www.ijhssi.org

Colbeck, I., \& Harrison, R.M. (1982) Tropospheric Ozone. In H. J. M Bowen ( Ed.), Environmental Chemistry (pp. 1-4), London; the Royal Society of Chemistry Burlington House

Cole, M. A., Elliott, R. J. R., \& Liu, B. (2020). The Impact of the Wuhan Covid-19 Lockdown on Air Pollution and Health: A Machine Learning and Augmented Synthetic Control Approach. Discussion Papers.

Collivignarelli, M. C., Abbà, A., Bertanza, G., Pedrazzani, R., Ricciardi, P., \& Carnevale Miino, M. (2020). Lockdown for CoViD-2019 in Milan: What are the effects on air quality? Science of The Total Environment, 732(February), 139280. https://doi.org/10.1016/j.scitotenv.2020.139280

Cox, R. M. (2003). The use of passive sampling to monitor forest exposure to 03, NO2 and SO2: A review and some case studies. Environmental Pollution, 126(3), 301-311. https://doi.org/10.1016/S0269-7491(03)00243-4

CPCB, (2014). National Air Quality Index. Central Pollution Control Board, Minstry of Environment, Forest and Climate Change, Government of India; Delhi, India.

Dadhich, A. P., Goyal, R., \& Dadhich, P. N. (2018). Assessment of spatio-temporal variations in air quality of Jaipur city, Rajasthan, India. Egyptian Journal of Remote Sensing and Space Science, 21(2), 173-181.

https://doi.org/10.1016/j.ejrs.2017.04.002

Das, R., Khezri, B., Srivastava, B., Datta, S., Sikdar, P. K., Webster, R. D., \& Wang, X. (2015). Trace element composition of PM2.5 and PM10 from kolkata-a heavily polluted indian metropolis. Atmospheric Pollution Research, 6(5), $742-750$. https://doi.org/10.5094/APR.2015.083

Datta, M., Barman, M., \& Manna, S. (2016). Living-dagerously-kolkata-hotspots.pdf. Toxics Links. 
David, N., P, L. V., Manzoor, S., \& Jorge, O. C. (2019). Statistical Tools for Air Pollution Assessment: Multivariate and, 2019.

Debnath, J., Majumder, D., \& Biswas, A. (2018). Air quality assessment using weighted interval type-2 fuzzy inference system. Ecological Informatics, 46, 133-146. https://doi.org/10.1016/j.ecoinf.2018.06.002

Ebi, K. L., \& McGregor, G. (2008). Climate change, tropospheric ozone and particulate matter, and health impacts. Environmental Health Perspectives, 116(11), 1449-1455. https://doi.org/10.1289/ehp.11463

Fan, C., Li, Y., Guang, J., Li, Z., Elnashar, A., Allam, M., \& de Leeuw, G. (2020). The Impact of the Control Measures during the COVID-19 Outbreak on Air Pollution in China. Remote Sensing, 12(10), 1613. https://doi.org/10.3390/rs12101613

Fenn, M. E., Bytnerowicz, A., Schilling, S. L., Vallano, D. M., Zavaleta, E. S., Weiss, S. B., et al. (2018). On-road emissions of ammonia: An underappreciated source of atmospheric nitrogen deposition. Science of the Total Environment, 625, 909919. https://doi.org/10.1016/j.scitotenv.2017.12.313

Fernandes, N. (2020). Economic Effects of Coronavirus Outbreak (COVID-19) on the World Economy. SSRN Electronic Journal. https://doi.org/10.2139/ssrn.3557504

Figueiredo, A., Codina, A., Moreira, D., Figueiredo, M., Saez, M., \& León, A. (2020). Impact of lockdown on COVID-19 incidence and mortality in China: an interrupted time series study. WHO Bulletin, (April). https://doi.org/10.2471/BLT.20.251561

Financial Express. (2020). Kolkata most polluted metro; India has highest PAH level, says Tokyo University study - The Financial Express. https://www.financialexpress.com/economy/kolkata-most-polluted-metro-india-has-highest-pah-levelsays-tokyo-university-study/3982/

Gaur, A., Tripathi, S. N., Kanawade, V. P., Tare, V., \& Shukla, S. P. (2014). Four-year measurements of trace gases (SO2, NOx, CO, and 03) at an urban location, Kanpur, in Northern India. Journal of Atmospheric Chemistry, 71(4), 283-301. https://doi.org/10.1007/s10874-014-9295-8

Gautam, S. (2020). The Influence of COVID-19 on Air Quality in India: A Boon or Inutile. Bulletin of Environmental Contamination and Toxicology, 104(6), 724-726. https://doi.org/10.1007/s00128-020-02877-y

Ghose, M. K., Paul, R., \& Banerjee, S. K. (2005). Assessment of the impact on human health of exposure to urban air pollutants: An Indian case study. International Journal of Environmental Studies, 62(2), 201-214.

https://doi.org/10.1080/0020723042000275123

GOI. (2020). Detail Question and Answers on COVID-19 for Public. Govt of India. https://www.mohfw.gov.in/pdf/MindingourmindsduringCoronaeditedat.pdf

Gupta, A. K., Karar, K., Ayoob, S., \& John, K. (2008). Spatio-temporal characteristics of gaseous and particulate pollutants in an urban region of Kolkata, India. Atmospheric Research, 87(2), 103-115.

https://doi.org/10.1016/j.atmosres.2007.07.008

Haque, M. S., \& Singh, R. B. (2017). Air pollution and human health in Kolkata, India: A case study. Climate, 5(4), 1-16. https://doi.org/10.3390/cli5040077

He, G., Pan, Y., \& Tanaka, T. (2020). COVID-19, City Lockdown, and Air Pollution: Evidence from China. medRxiv, 2020.03.29.20046649. https://doi.org/10.1101/2020.03.29.20046649

Page $13 / 27$ 
Ibe, F. C., Opara, A. I., Duru, C. E., Obinna, I. B., \& Enedoh, M. C. (2020). Statistical analysis of atmospheric pollutant concentrations in parts of Imo State, Southeastern Nigeria. Scientific African, 7.

https://doi.org/10.1016/j.sciaf.2019.e00237

Joshi, P. C., \& Mahadev, S. (2011). Distribution of air pollutants in ambient air of district Haridwar ( Uttarakhand ), India: A case study after establishment of State Industrial Development Corporation, 2(1), 249-270.

https://doi.org/10.6088/ijes.00202010026

Jumaah, H. J., Ameen, M. H., Kalantar, B., Rizeei, H. M., \& Jumaah, S. J. (2019). Air quality index prediction using IDW geostatistical technique and OLS-based GIS technique in Kuala Lumpur, Malaysia. Geomatics, Natural Hazards and Risk, 10(1), 2185-2199. https://doi.org/10.1080/19475705.2019.1683084

Kerimray, A., Baimatova, N., Ibragimova, O. P., Bukenov, B., Kenessov, B., Plotitsyn, P., \& Karaca, F. (2020). Assessing air quality changes in large cities during COVID-19 lockdowns: The impacts of traffic-free urban conditions in Almaty, Kazakhstan. Science of the Total Environment, 730, 139179. https://doi.org/10.1016/j.scitotenv.2020.139179

Lu, H., Stratton, C. W., \& Tang, Y. W. (2020). Outbreak of pneumonia of unknown etiology in Wuhan, China: The mystery and the miracle. Journal of Medical Virology, 92(4), 401-402. https://doi.org/10.1002/jmv.25678

Mahato, S., Pal, S., \& Ghosh, K. G. (2020). Science of the Total Environment Effect of lockdown amid COVID-19 pandemic on air quality of the megacity Delhi , India. Science of the Total Environment, 730, 139086.

https://doi.org/10.1016/j.scitotenv.2020.139086

Méndez-Arriaga, F. (2020). The temperature and regional climate effects on communitarian COVID-19 contagion in Mexico throughout phase 1. Science of The Total Environment, 735, 139560.

https://doi.org/https://doi.org/10.1016/j.scitotenv.2020.139560

Mukherjee, A., Mukherjee, G., Banerjp, U., \& Muichopadryay, S.P. (1998). Occupational exposure of the traffic, personnel of Calcutta to lead and carbon monoxide. Pollution Research. 17, 359-362

Nakada, L. Y. K., \& Urban, R. C. (2020). COVID-19 pandemic: Impacts on the air quality during the partial lockdown in São Paulo state, Brazil. Science of The Total Environment, 730(PG-139087-139087), 139087.

https://doi.org/10.1016/j.scitotenv.2020.139087

Njoku, P., Ibe, F. C., Alinnor, J., \& Opara, A. I. (2016). Seasonal Variability of Carbon Monoxide (CO) in the Ambient Environment of IMO State, Nigeria. International Letters of Natural Sciences, 53(May), 40-52.

https://doi.org/10.18052/www.scipress.com/ilns.53.40

Otmani, A., Benchrif, A., Tahri, M., Bounakhla, M., Chakir, E. M., El Bouch, M., \& Krombi, M. (2020). Impact of Covid-19 lockdown on PM10, SO2 and NO2 concentrations in Salé City (Morocco). Science of The Total Environment, 735(2), 139541. https://doi.org/10.1016/j.scitotenv.2020.139541

Poshtmasari, H. K., Sarvestani, Z. T., Kamkar, B., Shataei, S., \& Sadeghi, S. (2012). Comparison of Interpolation Methods for Estimating pH and EC in Agricultural Fields of Golestan Province. International Journal of Agriculture and Crop Sciences, 4(4), 157-167.

Roy, S. Sen, Singh, R. B., \& Kumar, M. (n.d.). An Analysis of Local Spatial Temperature Patterns in The Delhi Metropolitan Area. Physical Geography, (April 2015), 37-41. https://doi.org/10.2747/0272-3646.32.2.114 
Sicard, P., De Marco, A., Agathokleous, E., Feng, Z., Xu, X., Paoletti, E., et al. (2020). Amplified ozone pollution in cities during the COVID-19 lockdown. Science of The Total Environment, 735, 139542.

https://doi.org/https://doi.org/10.1016/j.scitotenv.2020.139542

Sikarwar, A., \& Rani, R. (2020). Assessing the immediate effect of COVID-19 lockdown on air quality: A case study of Delhi , India, 1-19.

Song, J., Guang, W., Li, L., \& Xiang, R. (2016). Assessment of air quality status in Wuhan, China. Atmosphere, 7(4). https://doi.org/10.3390/atmos7040056

Spiroska, J., Rahman, A., \& Pal, S. (2013). Air Pollution in Kolkata: An Analysis of Current Status and Interrelation between Different Factors. South East European University Review, 8(1), 182-214. https://doi.org/10.2478/v10306-0120012-7

Srivastava, S., Kumar, A., Bauddh, K., Gautam, A. S., \& Kumar, S. (2020). 21-Day Lockdown in India Dramatically Reduced Air Pollution Indices in Lucknow and New Delhi, India. Bulletin of environmental contamination and toxicology, (0123456789). https://doi.org/10.1007/s00128-020-02895-w

The Economics Times. (2020). india news: India observes Janata curfew, millions stay indoors - The Economic Times. https://economictimes.indiatimes.com/news/politics-and-nation/india-observes-janata-curfew-millions-stayindoors/articleshow/74756225.cms. Accessed 15 June 2020

Tobías, A., Carnerero, C., Reche, C., Massagué, J., Via, M., Minguillón, M. C., et al. (2020). Changes in air quality during the lockdown in Barcelona (Spain) one month into the SARS-CoV-2 epidemic. Science of the Total Environment, 726, 138540. https://doi.org/10.1016/j.scitotenv.2020.138540

Upadhyay, A., Kanchan, Goyal, P., Yerramilli, A., \& Gorai, A. K. (2014). Development of a fuzzy pattern recognition model for air quality assessment of Howrah City. Aerosol and Air Quality Research, 14(6), 1639-1652.

https://doi.org/10.4209/aaqr.2013.04.0118

Wang, Q., \& Su, M. (2020). A preliminary assessment of the impact of COVID-19 on environment - A case study of China. Science of the Total Environment, 728, 138915. https://doi.org/10.1016/j.scitotenv.2020.138915

Wang, T., Ding, A., Gao, J., \& Wu, W. S. (2006). Strong ozone production in urban plumes from Beijing, China. Geophysical Research Letters, 33(21), 1-5. https://doi.org/10.1029/2006GL027689

WHO Director-General's opening remarks at the media briefing on COVID-19 - 5 June 2020. (2020).

https://www.who.int/dg/speeches/detail/who-director-general-s-opening-remarks-at-the-media-briefing-on-covid-19--5june-2020. Accessed 7 June 2020

Zambrano-monserrate, M. A., Alejandra, M., \& Sanchez-alcalde, L. (2020). Science of the Total Environment Indirect effects of COVID-19 on the environment. Science of the Total Environment, 728, 138813.

https://doi.org/10.1016/j.scitotenv.2020.138813

\section{Tables}


Table:1 Location of the monitoring stations

\begin{tabular}{|c|c|c|c|}
\hline Municipal & Station ID & Name of the station & Location \\
\hline \multicolumn{4}{|l|}{ Corporation } \\
\hline \multirow[t]{7}{*}{ Kolkata } & K1 & Ballygunge & $22^{\circ} 32^{\prime} 12.3^{\prime \prime}, 88^{\circ} 21^{\prime} 49.69^{\prime \prime}$ \\
\hline & $\mathrm{K} 2$ & Fort William & $22^{\circ} 33^{\prime} 23.9^{\prime \prime}, 88^{\circ} 20^{\prime} 33.63^{\prime \prime}$ \\
\hline & K3 & Jadavpur & $22^{\circ} 29^{\prime} 57.44^{\prime \prime}, 88^{\circ} 22^{\prime} 9.01^{\prime \prime}$ \\
\hline & K4 & RabindraSarovar & $22^{\circ} 30^{\prime} 39.82^{\prime \prime}, 88^{\circ} 21^{\prime} 5.11^{\prime \prime}$ \\
\hline & K5 & Victoria & $22^{\circ} 32^{\prime} 41.31^{\prime \prime}, 88^{\circ} 20^{\prime} 25.33^{\prime \prime}$ \\
\hline & K6 & RabindraBharati & $22^{\circ} 37^{\prime} 40.35^{\prime \prime}, 88^{\circ} 22^{\prime} 49.44^{\prime \prime}$ \\
\hline & & University (RBU) & \\
\hline Bidhannagar & K7 & Bidhannagar & $22^{\circ} 34^{\prime} 53.65^{\prime \prime}, 88^{\circ} 24^{\prime} 36.09^{\prime \prime}$ \\
\hline \multirow[t]{3}{*}{ Howrah } & H1 & Belur Math & $22^{\circ} 37^{\prime} 47.28^{\prime \prime}, 88^{\circ} 21^{\prime} 7.26^{\prime \prime}$ \\
\hline & $\mathrm{H} 2$ & Ghusuri & $22^{\circ} 36^{\prime} 43.08^{\prime \prime}, 88^{\circ} 20^{\prime} 50.72^{\prime \prime}$ \\
\hline & H3 & Padmapukur & $22^{\circ} 34^{\prime} 7.43^{\prime \prime}, 88^{\circ} 16^{\prime} 47.02^{\prime \prime}$ \\
\hline
\end{tabular}

Table: 2 Proposed Breakpoints for AQI Scale 0-500

\begin{tabular}{|c|c|c|c|c|c|c|c|}
\hline AQI Category (Range) & $\mathrm{PM}_{10}$ & $\mathrm{PM}_{2.5}$ & $\mathrm{NO}_{2}$ & $\mathrm{O}_{3}$ & $\mathrm{CO}$ & $\mathrm{SO}_{2}$ & $\mathrm{NH}_{3}$ \\
& $24-\mathrm{hr}$ & $24-\mathrm{hr}$ & $24-\mathrm{hr}$ & $8-\mathrm{hr}$ & $8-\mathrm{hr}$ & $24-\mathrm{hr}$ & $24-\mathrm{hr}$ \\
& $\left(\mu \mathrm{g} / \mathrm{m}^{3}\right)$ & $\left(\mu \mathrm{g} / \mathrm{m}^{3}\right)$ & $\left(\mu \mathrm{g} / \mathrm{m}^{3}\right)$ & $\left(\mu \mathrm{g} / \mathrm{m}^{3}\right)$ & $\left(\mathrm{mg} / \mathrm{m}^{3}\right)$ & $\left(\mu \mathrm{g} / \mathrm{m}^{3}\right)$ & $\left(\mu \mathrm{g} / \mathrm{m}^{3}\right)$ \\
\hline Good (0-50) & $0-50$ & $0-30$ & $0-40$ & $0-50$ & $0-1.0$ & $0-40$ & $0-200$ \\
\hline Satisfactory (51-100) & $51-100$ & $31-60$ & $41-80$ & $51-100$ & $1.1-2.0$ & $41-80$ & $201-400$ \\
\hline Moderately Polluted (101-200) & $101-250$ & $61-90$ & $81-180$ & $101-168$ & $2.1-10$ & $81-380$ & $801-1200$ \\
\hline Poor(201-300) & $251-350$ & $91-120$ & $181-280$ & $169-208$ & $11-17$ & $381-800$ & $801-1200$ \\
\hline Very Poor (301-400) & $351-430$ & $121-250$ & $281-400$ & $209-748$ & $17-34$ & $801-1600$ & $1200-1800$ \\
\hline Severe (401-500) & $430+$ & $250+$ & $400+$ & $748+$ & $34+$ & $1600+$ & $1800+$ \\
\hline
\end{tabular}

Source: (СРCB, 2014) 
RabindraBharati, Kolkata

\begin{tabular}{|c|c|c|c|c|c|c|c|c|c|c|c|c|c|c|}
\hline & \multicolumn{2}{|c|}{$\mathrm{PM}_{2.5}\left(\mu \mathrm{g} / \mathrm{m}^{3}\right)$} & \multicolumn{2}{|c|}{$\mathrm{PM}_{10}\left(\mu \mathrm{g} / \mathrm{m}^{3}\right)$} & \multicolumn{2}{|c|}{$\mathrm{NO}_{2}\left(\mu \mathrm{g} / \mathrm{m}^{3}\right)$} & \multicolumn{2}{|c|}{$\mathrm{NH}_{3}\left(\mu \mathrm{g} / \mathrm{m}^{3}\right)$} & \multicolumn{2}{|c|}{$\mathrm{SO}_{2}\left(\mu \mathrm{g} / \mathrm{m}^{3}\right)$} & \multicolumn{2}{|c|}{$\mathrm{CO}\left(\mathrm{mg} / \mathrm{m}^{3}\right)$} & \multicolumn{2}{|c|}{$\mathrm{O}_{3}\left(\mu \mathrm{g} / \mathrm{m}^{3}\right)$} \\
\hline & PL & DL & PL & DL & PL & DL & PL & DL & PL & DL & PL & DL & PL & DL \\
\hline IAX & 140.38 & 68.87 & 313.5 & 114.97 & 71.16 & 28.56 & 66.96 & 39.06 & 23.97 & 16.17 & 1.05 & 0.35 & 46.25 & 62.56 \\
\hline IIN & 23.58 & 7.96 & 52.52 & 16.19 & 31.21 & 13.22 & 35.76 & 22.52 & 11.85 & 7.44 & 0.29 & 0.15 & 22.34 & 19.32 \\
\hline EAN & $73.7 \pm 27.7$ & $29.7 \pm 17.3$ & $136.6 \pm 52.8$ & $51.6 \pm 28.8$ & $52.0 \pm 9.1$ & $20.2 \pm 4.3$ & $46.9 \pm 6.9$ & $29.8 \pm 4.0$ & $17.5 \pm 3.0$ & $11.8 \pm 2.6$ & $0.5 \pm 0.1$ & $0.2 \pm 0.1$ & $34.0 \pm 6.1$ & $43.4 \pm 9.8$ \\
\hline
\end{tabular}

Fort William, Kolkata

\begin{tabular}{|c|c|c|c|c|c|c|c|c|c|c|c|c|c|c|}
\hline & \multicolumn{2}{|c|}{$\mathrm{PM}_{2.5}\left(\mu \mathrm{g} / \mathrm{m}^{3}\right)$} & \multicolumn{2}{|c|}{$\mathrm{PM}_{10}\left(\mu \mathrm{g} / \mathrm{m}^{3}\right)$} & \multicolumn{2}{|c|}{$\mathrm{NO}_{2}\left(\mu \mathrm{g} / \mathrm{m}^{3}\right)$} & \multicolumn{2}{|c|}{$\mathrm{NH}_{3}\left(\mu \mathrm{g} / \mathrm{m}^{3}\right)$} & \multicolumn{2}{|c|}{$\mathrm{SO}_{2}\left(\mu \mathrm{g} / \mathrm{m}^{3}\right)$} & \multicolumn{2}{|c|}{$\mathrm{CO}\left(\mathrm{mg} / \mathrm{m}^{3}\right)$} & \multicolumn{2}{|c|}{$\mathrm{O}_{3}\left(\mu \mathrm{g} / \mathrm{m}^{3}\right)$} \\
\hline & PL & DL & PL & DL & PL & DL & PL & DL & PL & DL & PL & DL & PL & DL \\
\hline IAX & 104.81 & 71.78 & 187.13 & 99.48 & 79.93 & 23.50 & 32.61 & 16.68 & 16.69 & 11.21 & 1.26 & 0.49 & 56.49 & 81.22 \\
\hline IIN & 26.39 & 8.99 & 54.51 & 16.70 & 31.50 & 5.99 & 16.35 & 5.57 & 3.23 & 3.72 & 0.44 & 0.28 & 8.82 & 15.99 \\
\hline EAN & $58.5 \pm 20.1$ & $32.3 \pm 17.8$ & $104.6 \pm 34.4$ & $50.1 \pm 20.4$ & $53.3 \pm 13.2$ & $12.5 \pm 4.2$ & $22.5 \pm 3.8$ & $9.1 \pm 3.3$ & $8.8 \pm 2.9$ & $6.6 \pm 1.9$ & $0.7 \pm 0.2$ & $0.4 \pm 0.1$ & $38.6 \pm 12.7$ & $46.9 \pm 12.9$ \\
\hline \multicolumn{15}{|c|}{ Victoria, Kolkata } \\
\hline & \multicolumn{2}{|c|}{$\mathrm{PM}_{2.5}\left(\mu \mathrm{g} / \mathrm{m}^{3}\right)$} & \multicolumn{2}{|c|}{$\mathrm{PM}_{10}\left(\mu \mathrm{g} / \mathrm{m}^{3}\right)$} & \multicolumn{2}{|c|}{$\mathrm{NO}_{2}\left(\mu \mathrm{g} / \mathrm{m}^{3}\right)$} & \multicolumn{2}{|c|}{$\mathrm{NH}_{3}\left(\mu \mathrm{g} / \mathrm{m}^{3}\right)$} & \multicolumn{2}{|c|}{$\mathrm{SO}_{2}\left(\mu \mathrm{g} / \mathrm{m}^{3}\right)$} & \multicolumn{2}{|c|}{$\mathrm{CO}\left(\mathrm{mg} / \mathrm{m}^{3}\right)$} & \multicolumn{2}{|c|}{$\mathrm{O}_{3}\left(\mu \mathrm{g} / \mathrm{m}^{3}\right)$} \\
\hline & PL & DL & PL & DL & PL & DL & PL & DL & PL & DL & PL & DL & PL & DL \\
\hline IAX & 107.03 & 49.46 & 216.61 & 82.93 & 84.08 & 27.57 & 33.20 & 29.25 & 23.73 & 16.50 & 2.28 & 1.77 & 92.60 & 108.53 \\
\hline IIN & 23.13 & 9.19 & 55.20 & 27.15 & 28.00 & 5.65 & 19.65 & 16.78 & 6.34 & 6.15 & 0.44 & 0.44 & 10.01 & 24.02 \\
\hline EAN & $57.4 \pm 22.1$ & $25.3 \pm 10.7$ & $117.5 \pm 45.3$ & $46.1 \pm 17.3$ & $60.0 \pm 15.2$ & $13.4 \pm 4.9$ & $25.3 \pm 3.2$ & $22.1 \pm 3.2$ & $12.1 \pm 4.0$ & $10.2 \pm 2.7$ & $1.5 \pm 0.4$ & $0.8 \pm 0.4$ & $57.3 \pm 20.7$ & $54.7 \pm 27.8$ \\
\hline
\end{tabular}




\begin{tabular}{|c|c|c|c|c|c|c|c|c|c|c|c|c|c|c|}
\hline & \multicolumn{2}{|c|}{$\mathrm{PM}_{2.5}\left(\mu \mathrm{g} / \mathrm{m}^{3}\right)$} & \multicolumn{2}{|l|}{$\mathrm{PM}_{10}\left(\mu \mathrm{g} / \mathrm{m}^{3}\right)$} & \multicolumn{2}{|c|}{$\mathrm{NO}_{2}\left(\mu \mathrm{g} / \mathrm{m}^{3}\right)$} & \multicolumn{2}{|l|}{$\mathrm{NH}_{3}\left(\mu \mathrm{g} / \mathrm{m}^{3}\right)$} & \multicolumn{2}{|c|}{$\mathrm{SO}_{2}\left(\mu \mathrm{g} / \mathrm{m}^{3}\right)$} & \multicolumn{2}{|l|}{$\mathrm{CO}\left(\mathrm{mg} / \mathrm{m}^{3}\right)$} & \multicolumn{2}{|l|}{$\mathrm{O}_{3}\left(\mu \mathrm{g} / \mathrm{m}^{3}\right)$} \\
\hline & PL & DL & PL & DL & PL & DL & PL & DL & PL & $\mathrm{DL}$ & PL & DL & PL & DL \\
\hline MAX & 149.68 & 62.07 & 241.35 & 27.83 & 46.29 & 9.89 & 25.77 & 10.28 & 14.58 & 8.75 & 1.17 & 0.44 & 79.07 & 82.58 \\
\hline MIN & 31.61 & 4.4 & 82.15 & 20.12 & 12.76 & 2.34 & 11.56 & 3.27 & 4.09 & 1.38 & 0.33 & 0.21 & 18.7 & 28.76 \\
\hline MEAN & $78.8 \pm 32.1$ & $25.4 \pm 15.1$ & $144.5 \pm 46.5$ & $60.9 \pm 40.8$ & $28.0 \pm 8.6$ & $5.63 \pm 1.97$ & $15.99 \pm 4.58$ & $6.61 \pm 2.12$ & $8.20 \pm 2.57$ & $4.49 \pm 2.00$ & $0.68 \pm 0.21$ & $0.29 \pm 0.05$ & $50.6 \pm 15.0$ & $51.8 \pm 16.2$ \\
\hline \multicolumn{15}{|c|}{ RabindraSarovar, Kolkata } \\
\hline & \multicolumn{2}{|c|}{$\mathrm{PM}_{2.5}\left(\mu \mathrm{g} / \mathrm{m}^{3}\right)$} & \multicolumn{2}{|l|}{$\mathrm{PM}_{10}\left(\mu \mathrm{g} / \mathrm{m}^{3}\right)$} & \multicolumn{2}{|c|}{$\mathrm{NO}_{2}\left(\mu \mathrm{g} / \mathrm{m}^{3}\right)$} & \multicolumn{2}{|l|}{$\mathrm{NH}_{3}\left(\mu \mathrm{g} / \mathrm{m}^{3}\right)$} & \multicolumn{2}{|c|}{$\mathrm{SO}_{2}\left(\mu \mathrm{g} / \mathrm{m}^{3}\right)$} & \multicolumn{2}{|l|}{$\mathrm{CO}\left(\mathrm{mg} / \mathrm{m}^{3}\right)$} & \multicolumn{2}{|l|}{$\mathrm{O}_{3}\left(\mu \mathrm{g} / \mathrm{m}^{3}\right)$} \\
\hline & PL & $\mathrm{DL}$ & PL & DL & PL & DL & PL & DL & PL & $\mathrm{DL}$ & PL & DL & PL & DL \\
\hline MIN & 26.75 & 2.09 & 47.24 & 14.36 & 8.27 & 5.24 & 4.32 & 7.27 & 6.87 & 3.94 & 0.23 & 0.15 & 14.43 & 24.63 \\
\hline MEAN & $50.6 \pm 17.8$ & $16.8 \pm 13.3$ & $102.7 \pm 36.2$ & $46.8 \pm 20.6$ & $26.2 \pm 20.6$ & $8.1 \pm 1.9$ & $14.0 \pm 5.2$ & $13.0 \pm 4.5$ & $13.2 \pm 3.8$ & $7.1 \pm 2.7$ & $0.6 \pm 0.2$ & $0.3 \pm 0.05$ & $42.5 \pm 13.0$ & $48.9 \pm 13.9$ \\
\hline \multicolumn{15}{|c|}{ Jadavpur, Kolkata } \\
\hline & \multicolumn{2}{|c|}{$\mathrm{PM}_{2.5}\left(\mu \mathrm{g} / \mathrm{m}^{3}\right)$} & \multicolumn{2}{|l|}{$\mathrm{PM}_{10}\left(\mu \mathrm{g} / \mathrm{m}^{3}\right)$} & \multicolumn{2}{|c|}{$\mathrm{NO}_{2}\left(\mu \mathrm{g} / \mathrm{m}^{3}\right)$} & \multicolumn{2}{|c|}{$\mathrm{NH}_{3}\left(\mu \mathrm{g} / \mathrm{m}^{3}\right)$} & \multicolumn{2}{|c|}{$\mathrm{SO}_{2}\left(\mu \mathrm{g} / \mathrm{m}^{3}\right)$} & \multicolumn{2}{|l|}{$\mathrm{CO}\left(\mathrm{mg} / \mathrm{m}^{3}\right)$} & \multicolumn{2}{|l|}{$\mathrm{O}_{3}\left(\mathrm{\mu g} / \mathrm{m}^{3}\right)$} \\
\hline & PL & $\mathrm{DL}$ & PL & DL & PL & DL & PL & DL & PL & $\mathrm{DL}$ & PL & DL & PL & DL \\
\hline MAX & 93.61 & 60.96 & 172.4 & 100.01 & 52.38 & 17.62 & 79.76 & 15.83 & 11.96 & 12.35 & 1.69 & 0.58 & 37.48 & 61.22 \\
\hline MIN & 20 & 6.46 & 54.66 & 19.0 & 20.24 & 7.31 & 15.04 & 5.81 & 4.75 & 4.84 & 0.54 & 0.39 & 7.45 & 17.75 \\
\hline
\end{tabular}

Belur Math, Howrah

\begin{tabular}{|c|c|c|c|c|c|c|c|c|c|c|c|c|c|c|}
\hline & \multicolumn{2}{|c|}{$\mathrm{PM}_{2.5}\left(\mu \mathrm{g} / \mathrm{m}^{3}\right)$} & \multicolumn{2}{|c|}{$\mathrm{PM}_{10}\left(\mu \mathrm{g} / \mathrm{m}^{3}\right)$} & \multicolumn{2}{|c|}{$\mathrm{NO}_{2}\left(\mu \mathrm{g} / \mathrm{m}^{3}\right)$} & \multicolumn{2}{|c|}{$\mathrm{NH}_{3}\left(\mu \mathrm{g} / \mathrm{m}^{3}\right)$} & \multicolumn{2}{|c|}{$\mathrm{SO}_{2}\left(\mu \mathrm{g} / \mathrm{m}^{3}\right)$} & \multicolumn{2}{|c|}{$\mathrm{CO}\left(\mathrm{mg} / \mathrm{m}^{3}\right)$} & \multicolumn{2}{|c|}{$\mathrm{O}_{3}\left(\mu \mathrm{g} / \mathrm{m}^{3}\right)$} \\
\hline & PL & DL & PL & DL & PL & DL & PL & DL & PL & DL & PL & DL & PL & DL \\
\hline IAX & 67.34 & 38.00 & 159.53 & 86.02 & 97.42 & 29.11 & 41.47 & 17.89 & 31.60 & 18.64 & 1.01 & 0.44 & NA & NA \\
\hline IIN & 15.42 & 4.48 & 43.77 & 14.58 & 32.04 & 11.19 & 20.02 & 8.39 & 10.76 & 7.67 & 0.28 & 0.20 & NA & NA \\
\hline EAN & $41.57 \pm 13.7$ & $18.97 \pm 9.0$ & $99.37 \pm 29.6$ & $41.57 \pm 18.2$ & $61.73 \pm 13.5$ & $18.99 \pm 4.5$ & $29.26 \pm 5.5$ & $11.89 \pm 2.4$ & $21.76 \pm 3.8$ & $12.63 \pm 3.1$ & $0.61 \pm 0.2$ & $0.31 \pm 0.1$ & NA & NA \\
\hline \multicolumn{15}{|c|}{ Ghusuri, Howrah } \\
\hline & \multicolumn{2}{|c|}{$\mathrm{PM}_{2.5}\left(\mu \mathrm{g} / \mathrm{m}^{3}\right)$} & \multicolumn{2}{|c|}{$\mathrm{PM}_{10}\left(\mu \mathrm{g} / \mathrm{m}^{3}\right)$} & \multicolumn{2}{|c|}{$\mathrm{NO}_{2}\left(\mu \mathrm{g} / \mathrm{m}^{3}\right)$} & \multicolumn{2}{|c|}{$\mathrm{NH}_{3}\left(\mu \mathrm{g} / \mathrm{m}^{3}\right)$} & \multicolumn{2}{|c|}{$\mathrm{SO}_{2}\left(\mu \mathrm{g} / \mathrm{m}^{3}\right)$} & \multicolumn{2}{|c|}{$\mathrm{CO}\left(\mathrm{mg} / \mathrm{m}^{3}\right)$} & \multicolumn{2}{|c|}{$\mathrm{O}_{3}\left(\mu \mathrm{g} / \mathrm{m}^{3}\right)$} \\
\hline & PL & DL & PL & DL & PL & DL & PL & DL & PL & DL & PL & DL & PL & DL \\
\hline IAX & 145.7 & 64.99 & 333.52 & 134.95 & 73.42 & 24.04 & 21.36 & 15.35 & 67.39 & 17.78 & 1.16 & 0.65 & 28.69 & 62.26 \\
\hline IIN & 36.13 & 12.20 & 105.69 & 29.44 & 26.30 & 10.50 & 12.04 & 9.28 & 16.02 & 5.73 & 0.36 & 0.22 & 8.53 & 18.39 \\
\hline EAN & $83.2 \pm 29.5$ & $30.2 \pm 12.3$ & $198.4 \pm 63.0$ & $73.1 \pm 29.8$ & $53.2 \pm 12.7$ & $15.9 \pm 3.3$ & $17.2 \pm 2.8$ & $11.7 \pm 1.7$ & $36.4 \pm 13.8$ & $8.8 \pm 2.6$ & $0.81 \pm 0.2$ & $0.35 \pm 0.1$ & $19.2 \pm 4.9$ & $36.5 \pm 10.0$ \\
\hline
\end{tabular}

Padmapukur, Howrah

\begin{tabular}{|c|c|c|c|c|c|c|c|c|c|c|c|c|c|c|}
\hline & \multicolumn{2}{|c|}{$\mathrm{PM}_{2.5}\left(\mu \mathrm{g} / \mathrm{m}^{3}\right)$} & \multicolumn{2}{|c|}{$\mathrm{PM}_{10}\left(\mu \mathrm{g} / \mathrm{m}^{3}\right)$} & \multicolumn{2}{|c|}{$\mathrm{NO}_{2}\left(\mu \mathrm{g} / \mathrm{m}^{3}\right)$} & \multicolumn{2}{|c|}{$\mathrm{NH}_{3}\left(\mu \mathrm{g} / \mathrm{m}^{3}\right)$} & \multicolumn{2}{|c|}{$\mathrm{SO}_{2}\left(\mu \mathrm{g} / \mathrm{m}^{3}\right)$} & \multicolumn{2}{|c|}{$\mathrm{CO}\left(\mathrm{mg} / \mathrm{m}^{3}\right)$} & \multicolumn{2}{|c|}{$\mathrm{O}_{3}\left(\mu \mathrm{g} / \mathrm{m}^{3}\right)$} \\
\hline & PL & DL & PL & DL & PL & DL & $\mathrm{PL}$ & DL & PL & DL & PL & DL & PL & DL \\
\hline IAX & 136.36 & 52.13 & 214.64 & 91.64 & 71.99 & 17.18 & 40.05 & 7.20 & 33.92 & 21.41 & 0.97 & 0.53 & 62.73 & 81.69 \\
\hline IIN & 25.74 & 10.29 & 47.81 & 17.56 & 6.92 & 2.05 & 8.83 & 3.25 & 2.30 & 4.76 & 0.38 & 0.34 & 9.54 & 8.72 \\
\hline EAN & $71.2 \pm 27.0$ & $29.6 \pm 11.5$ & $118.5 \pm 42.8$ & $52.8 \pm 22.1$ & $33.5 \pm 11.9$ & $10.4 \pm 4.5$ & $23.3 \pm 10.8$ & $4.7 \pm 0.9$ & $10.9 \pm 7.7$ & $10.7 \pm 3.4$ & $0.63 \pm 0.2$ & $0.44 \pm 0.1$ & $37.8 \pm 15.2$ & $48.5 \pm 16.6$ \\
\hline
\end{tabular}


Table: 4 Two-way ANOVA test for AQI based on stations and time

\begin{tabular}{lcccc}
\hline Source & Sum of Squares & Degree of Freedom & Mean Squares & F-Values \\
\hline Time & 779793.621 & 1 & 779793.621 & $465.723^{* *}$ \\
Station & 193417.517 & 8 & 24177.190 & $14.440^{* *}$ \\
\hline Time*Station & 80973.525 & 8 & 10121.691 & $6.045^{* *}$ \\
\hline Error & 994577.145 & 594 & 1674.372 & \\
\hline Total & 6860202.710 & 612 & & \\
\hline
\end{tabular}

( $* *$ is ' $\mathrm{F}^{\prime}$ Significant at $\mathrm{P}<0.01$ )(Source: Computed by author)

\section{Figures}

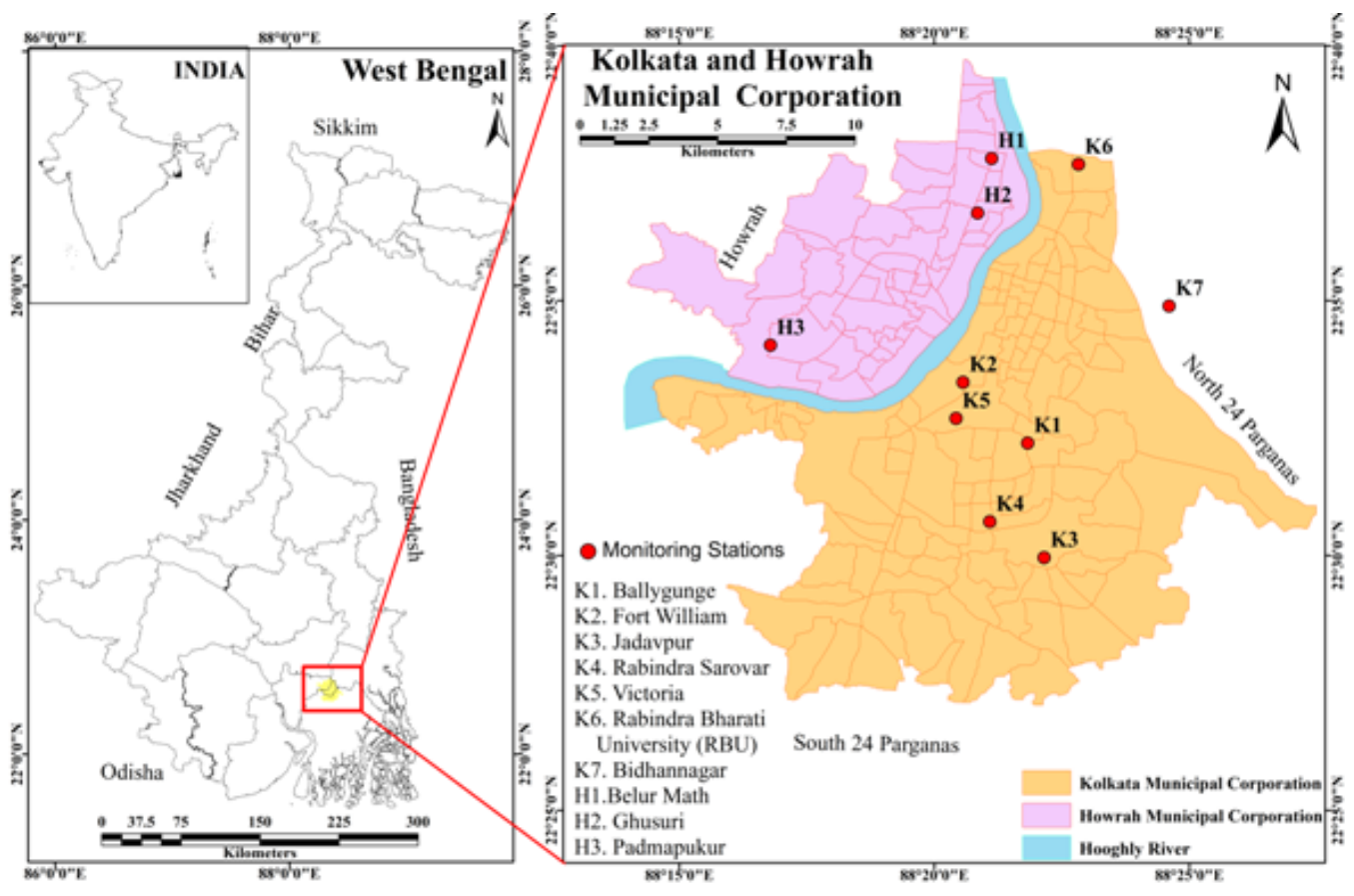

Figure 1

Location of the study area 


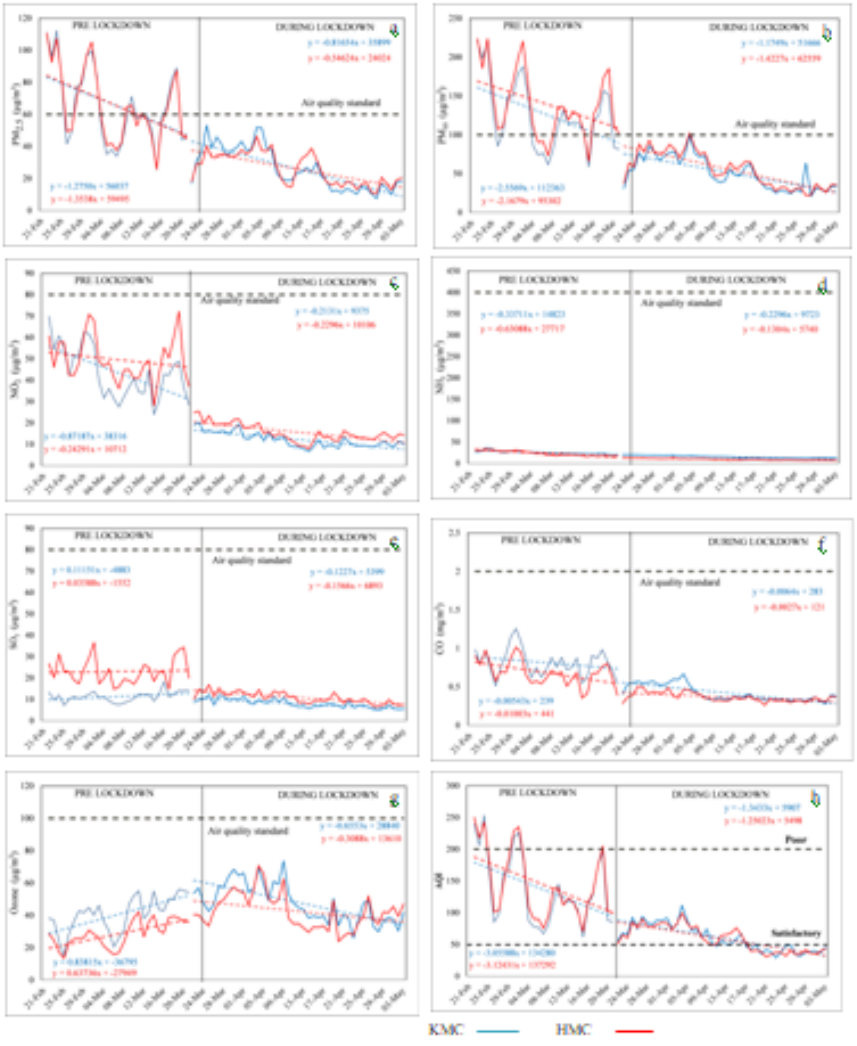

Figure 2

24 hours mean concentrations of (a) PM2.5, (b) PM10, (c) NO2, (d) NH3 (e)SO2 (h) AQI and 8 hours mean concentrations of (e) CO \& (f) 03 between 22nd February to 3rd May, 2020 in Kolkata and Howrah

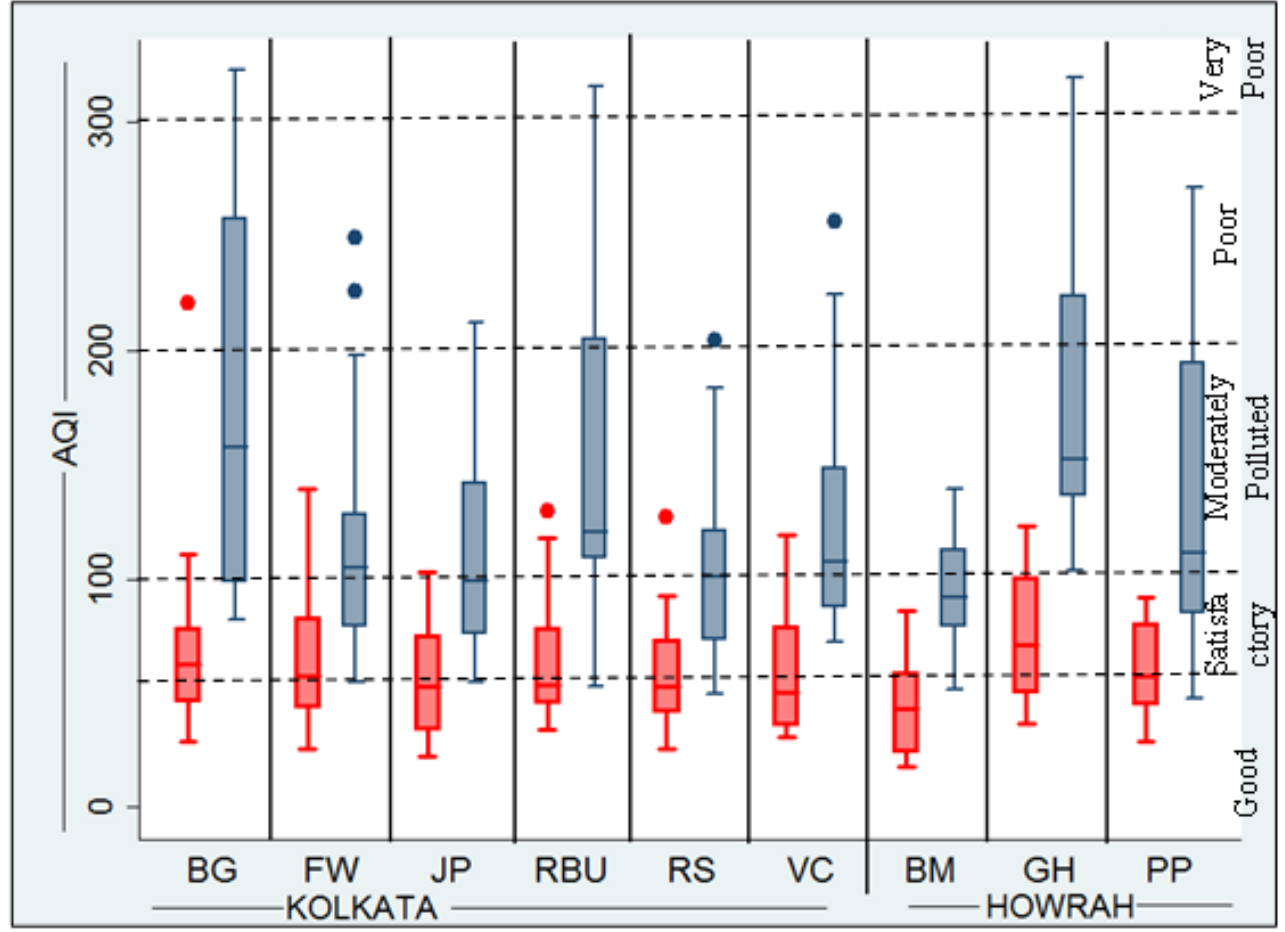

During Lockdown

Pre-lockdown

Figure 3 
Box plot comparing AQI distribution for nine monitoring stations between pre-lockdown and duringlockdown phase (BGBallygunge, FW- Fort William, JP- Jadavpur, RBU-RabindraBhararti University, RS-RabindraSarovar, VC-Victoria, BM- Melur Math, GH-Ghusuri, PP-Padmapukur)
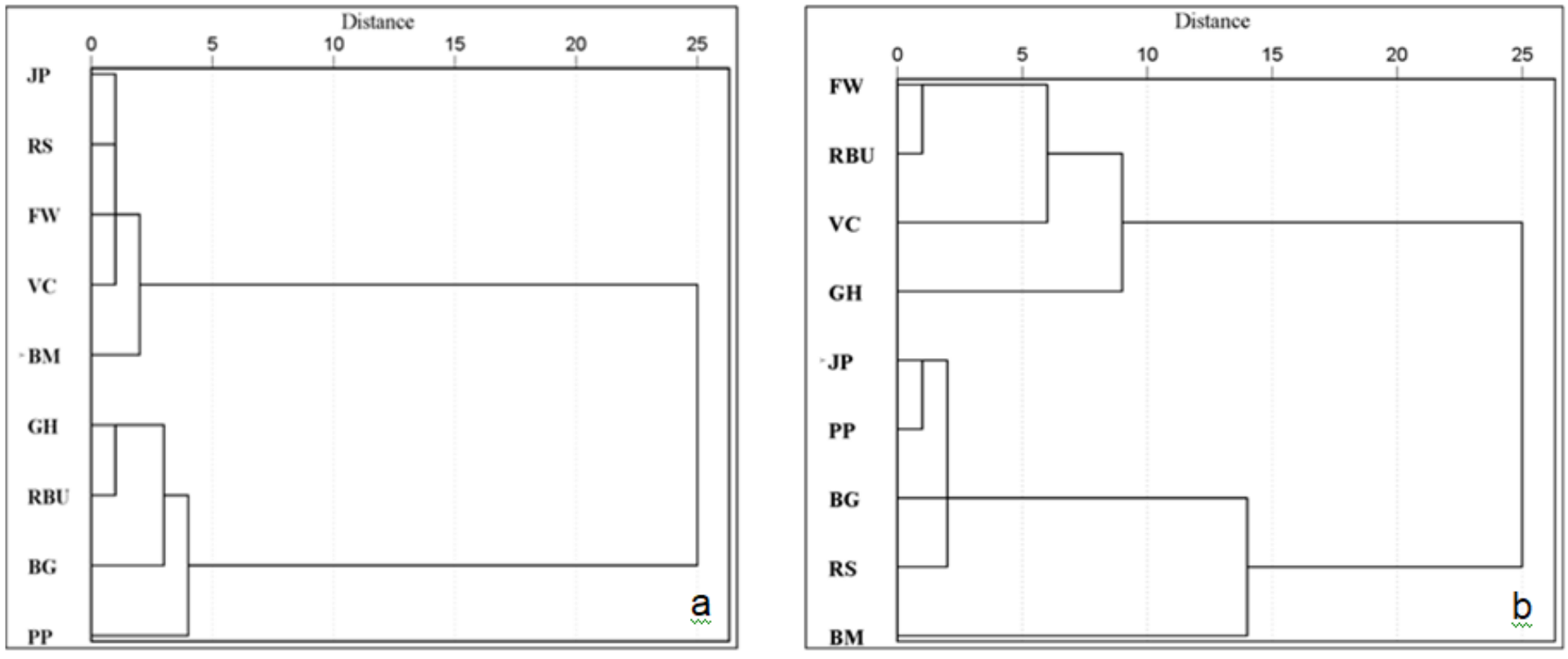

Figure 4

Cluster analysis of the stations in the (a) pre-lockdown (b)during lockdown period (BG-Ballygunge, FW- Fort William, JPJadavpur, RBU-RabindraBhararti University, RS-RabindraSarovar, VC-Victoria, BM- Melur Math, GH-Ghusuri, PPPadmapukur)
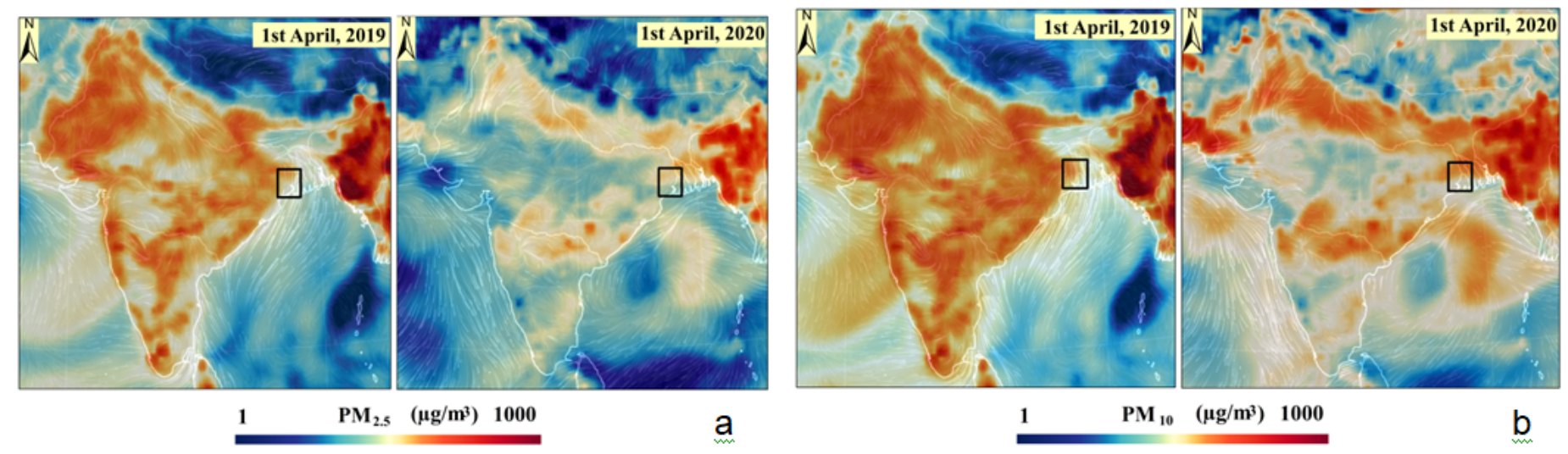

Figure 5

Change in concentration from 1st April, 2019 to 2020 of PM2.5 (5a) and PM10 (5b) 


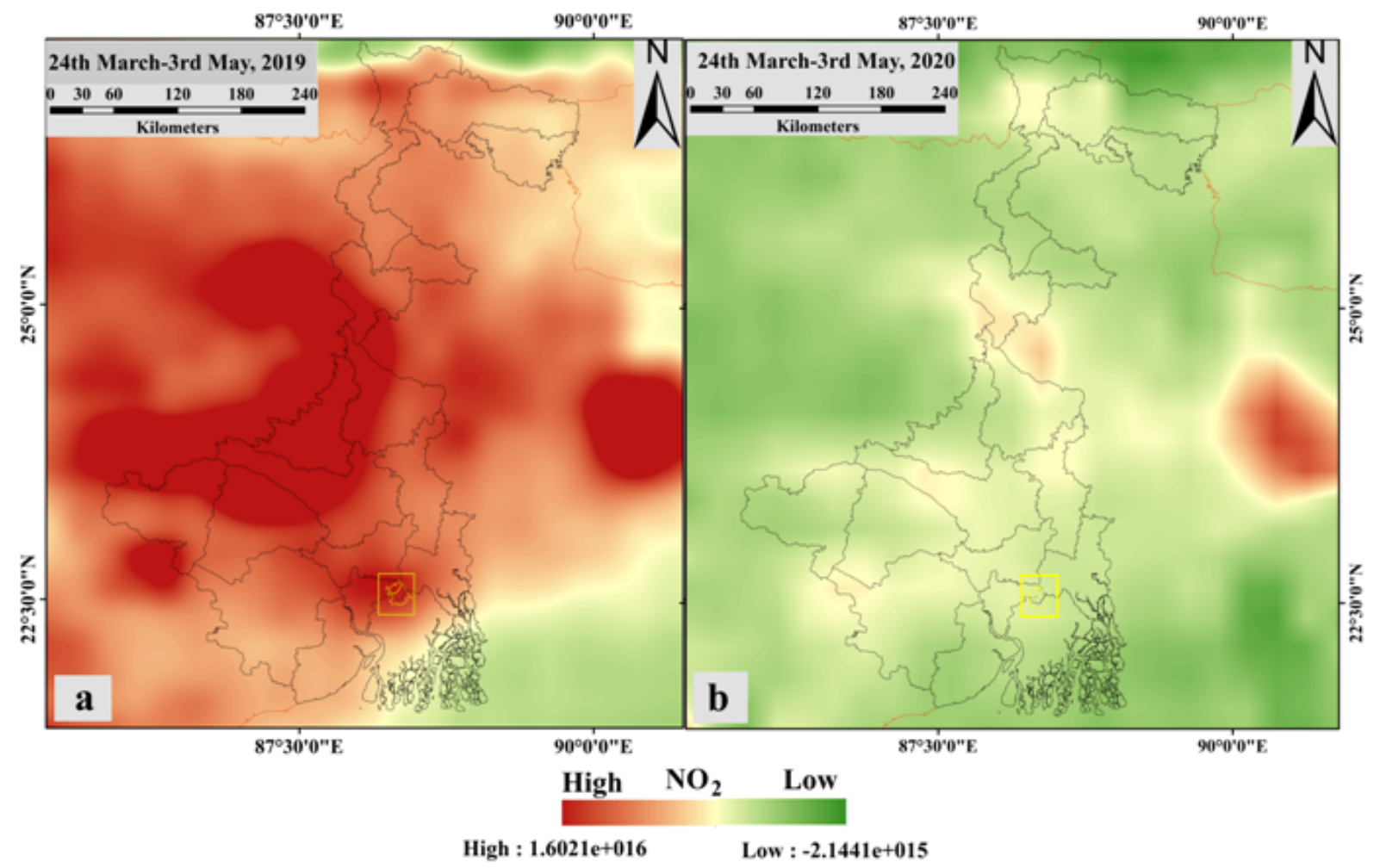

Figure 6

24hours Timely Averaged Map of NO2 (1/cm2) from (6a) 24th March to 3rd May, 2019 (6b) 24th March to 3rd May, 2020
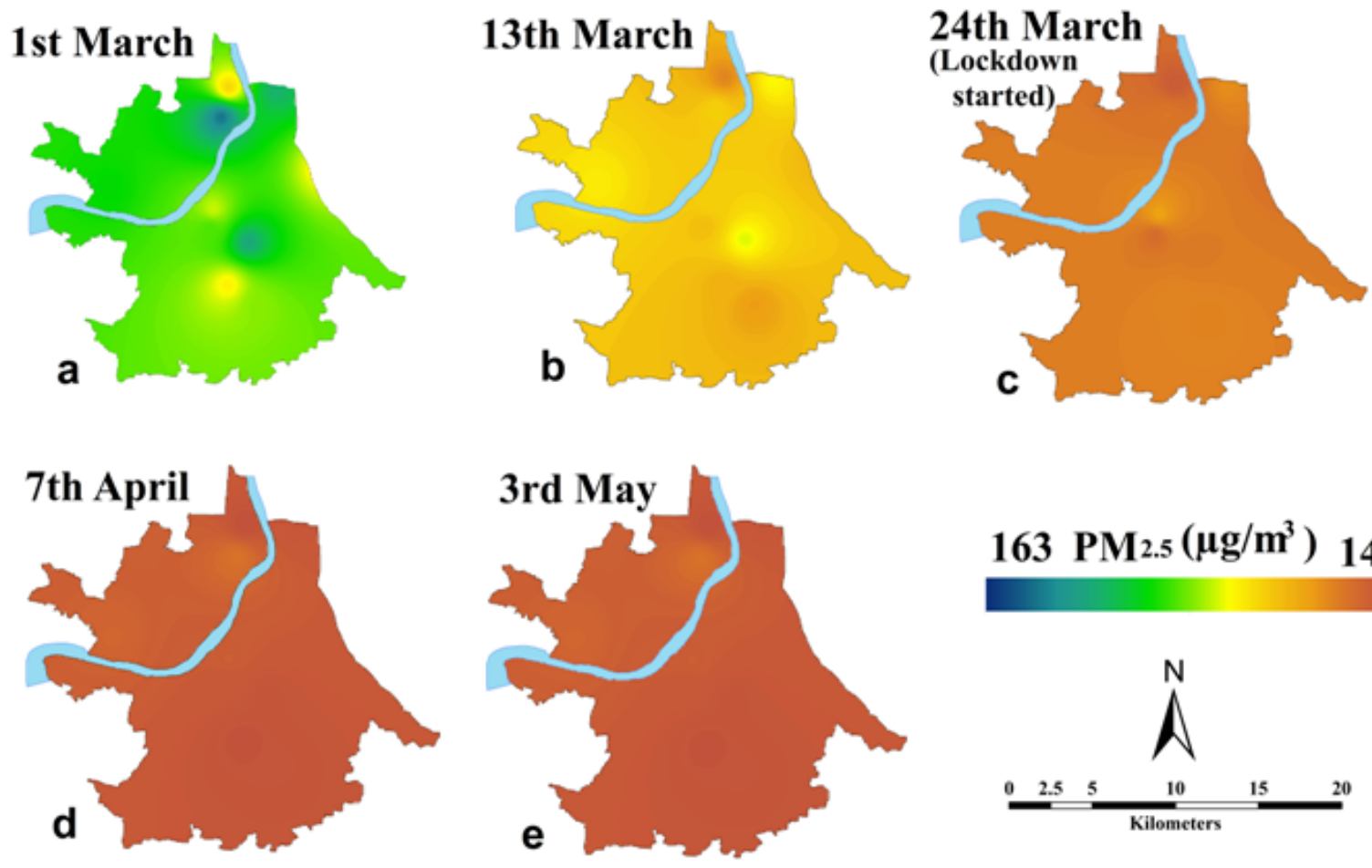

\section{$163 \operatorname{PM} 2.5\left(\mu \mathrm{g} / \mathrm{m}^{3}\right) 14$}

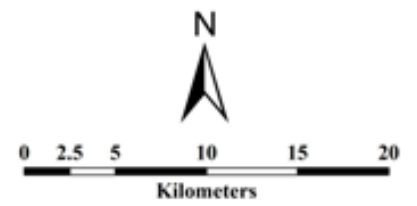

Figure 7

Spatio- temporal change of PM 2.5 (2020) 

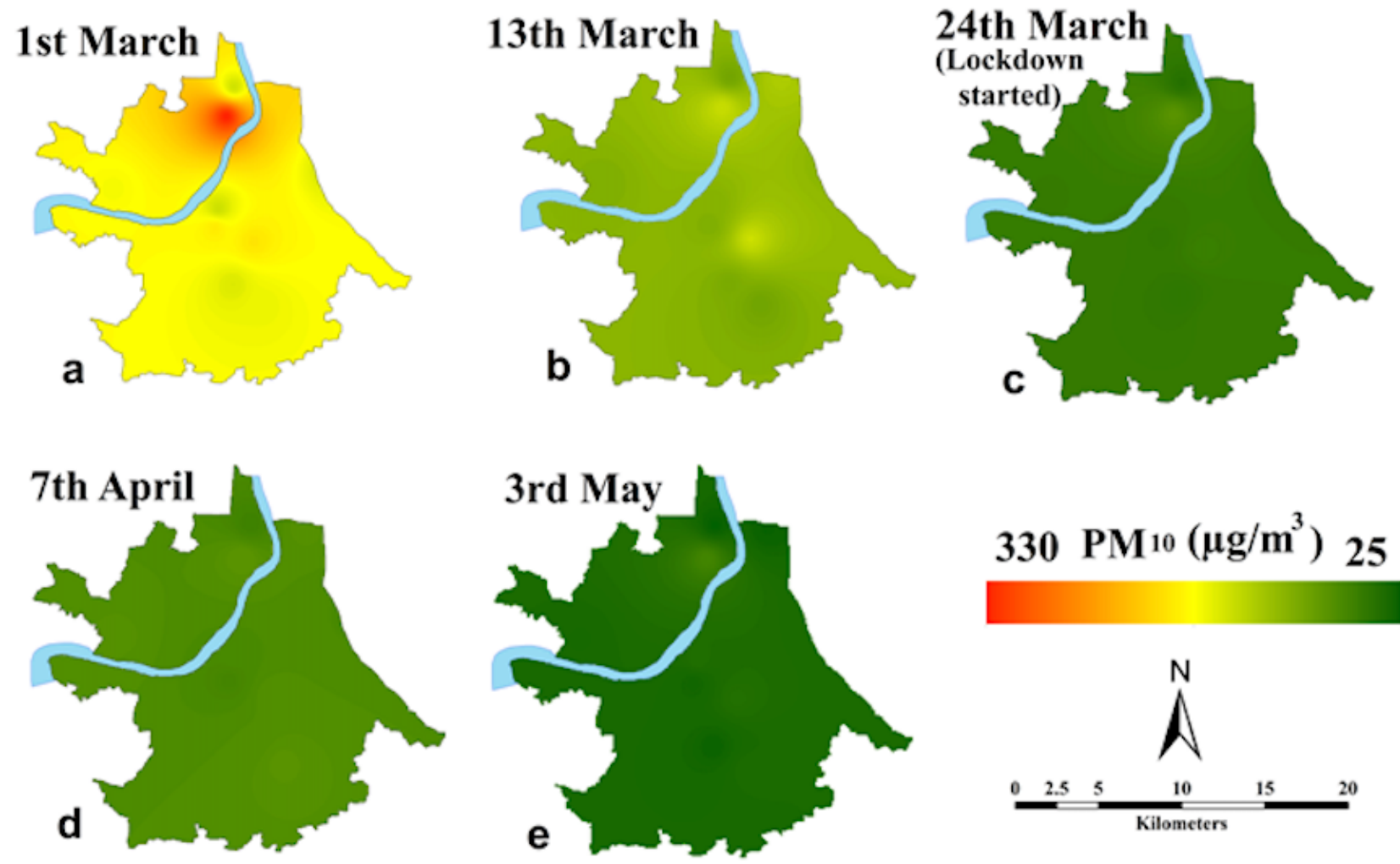

Figure 8

Spatio- temporal change of PM 10 (2020)
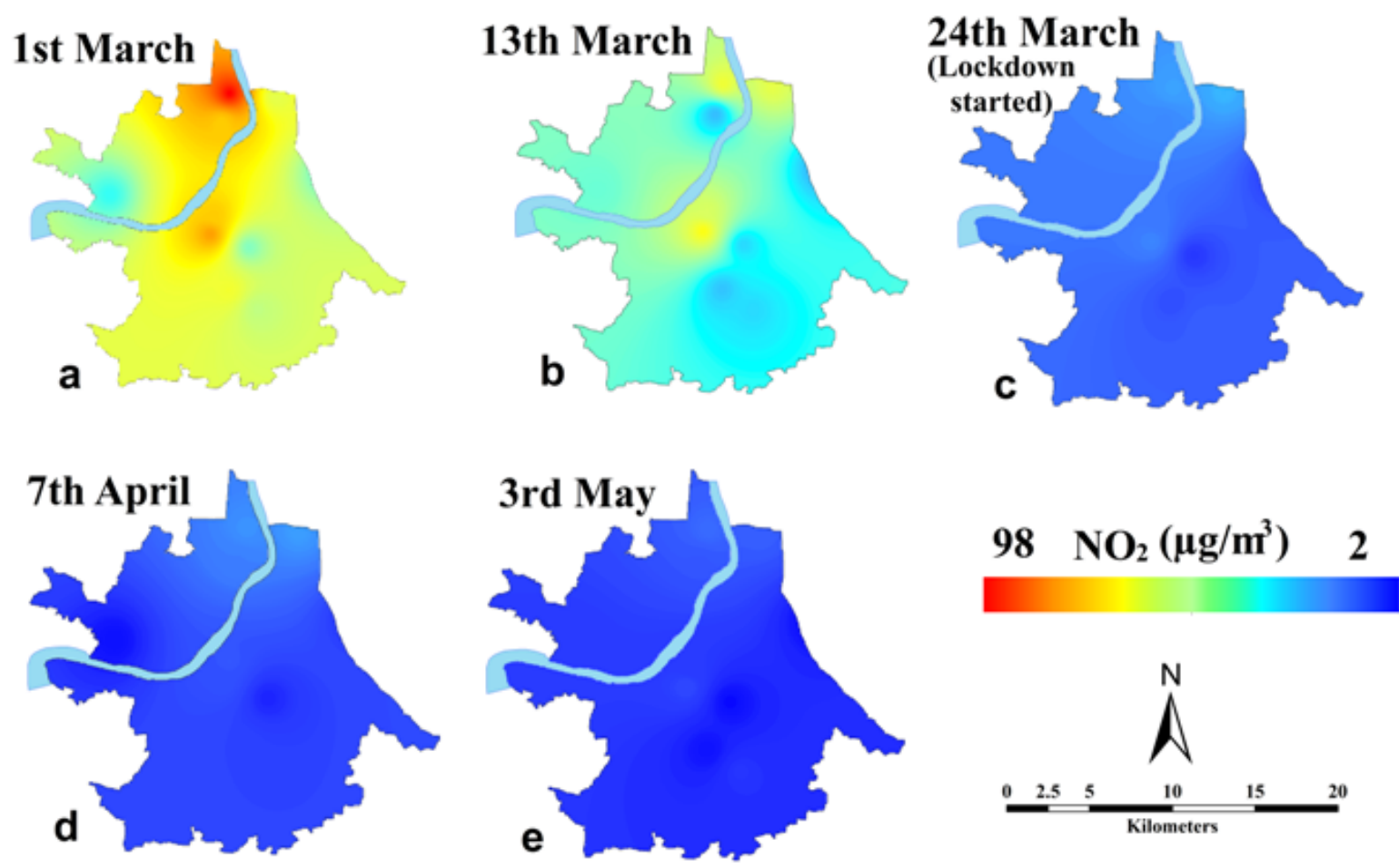
Figure 9

Spatio- temporal change of NO2 (2020)
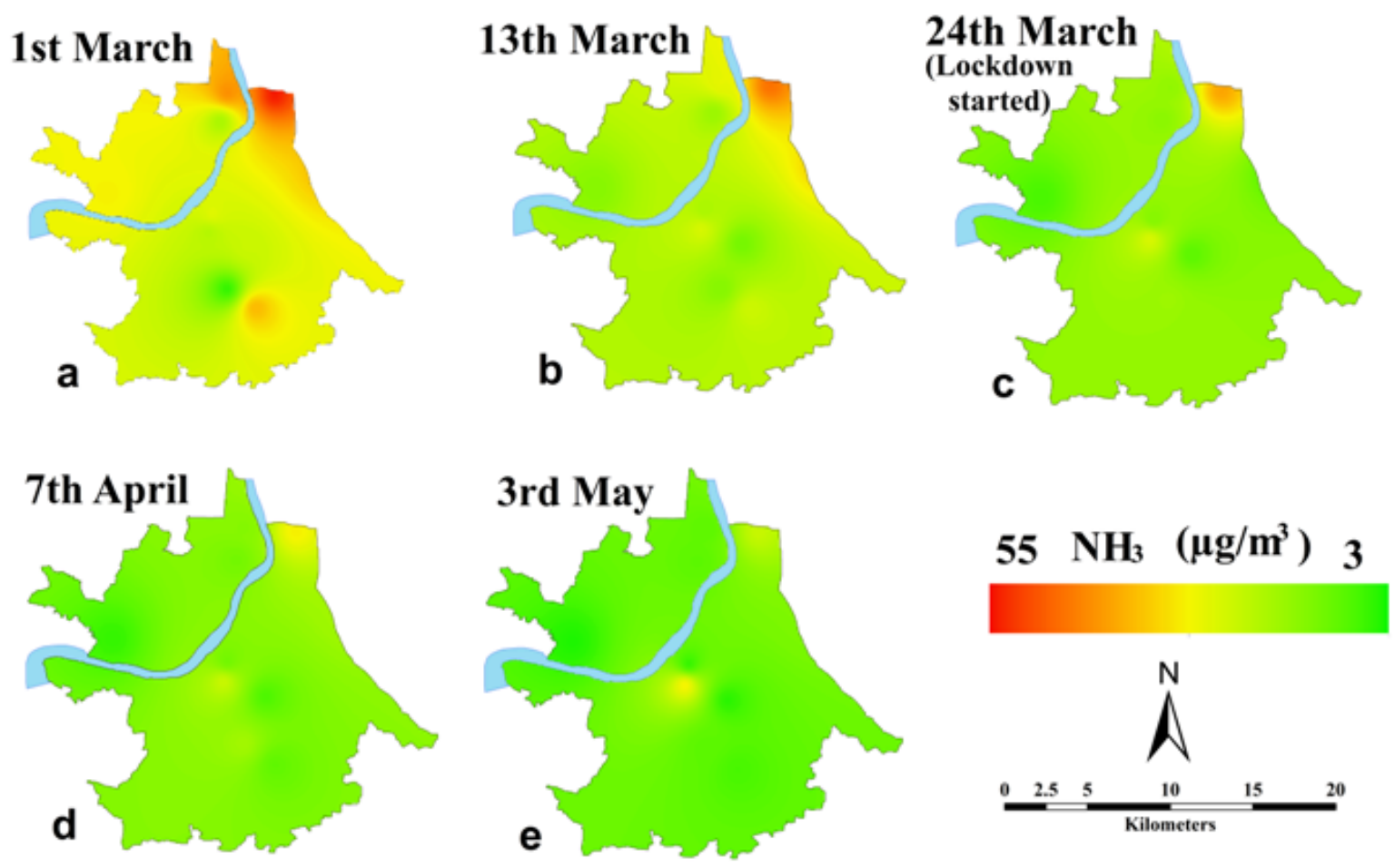

Figure 10

Spatio- temporal change of NH3 (2020)
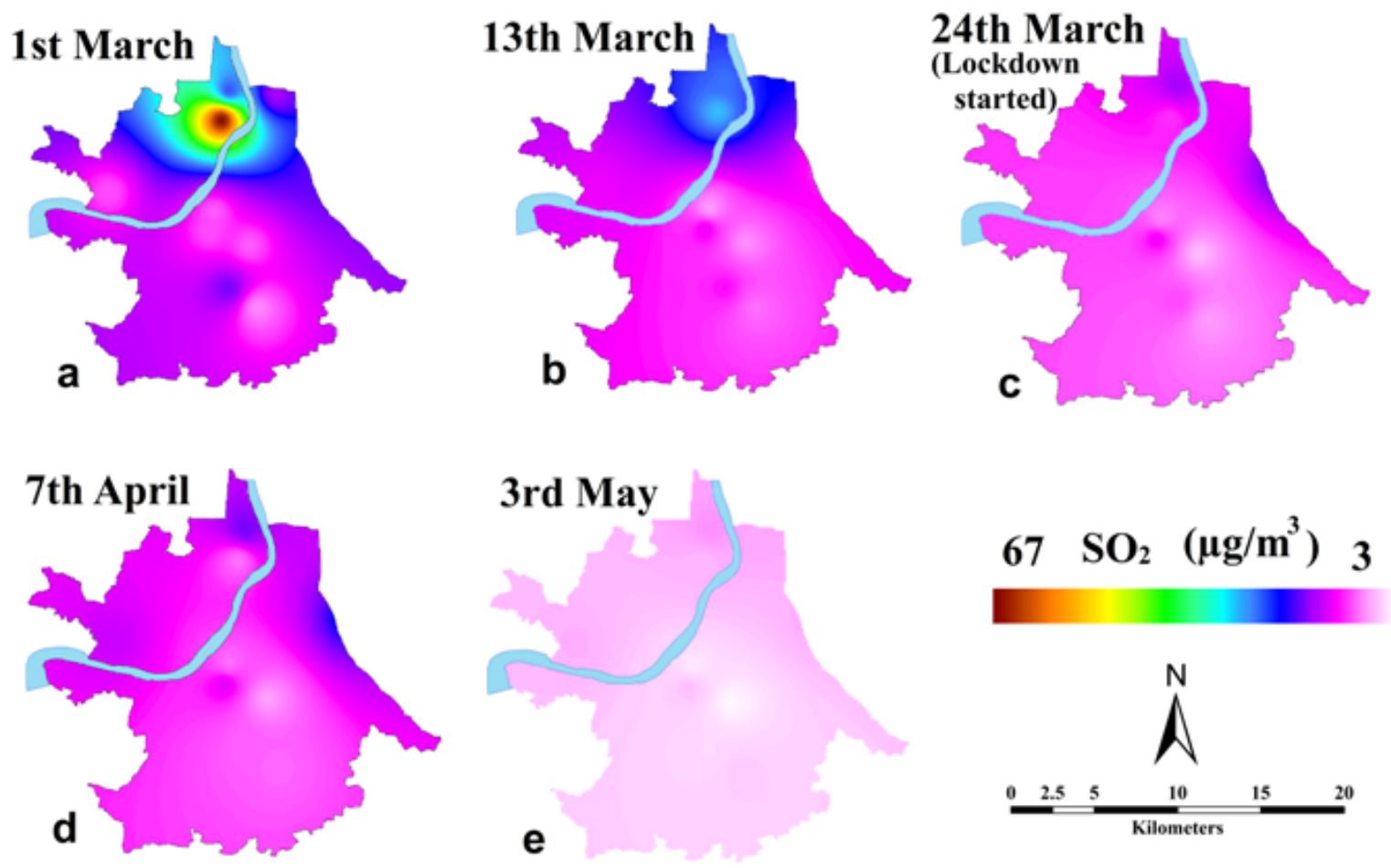

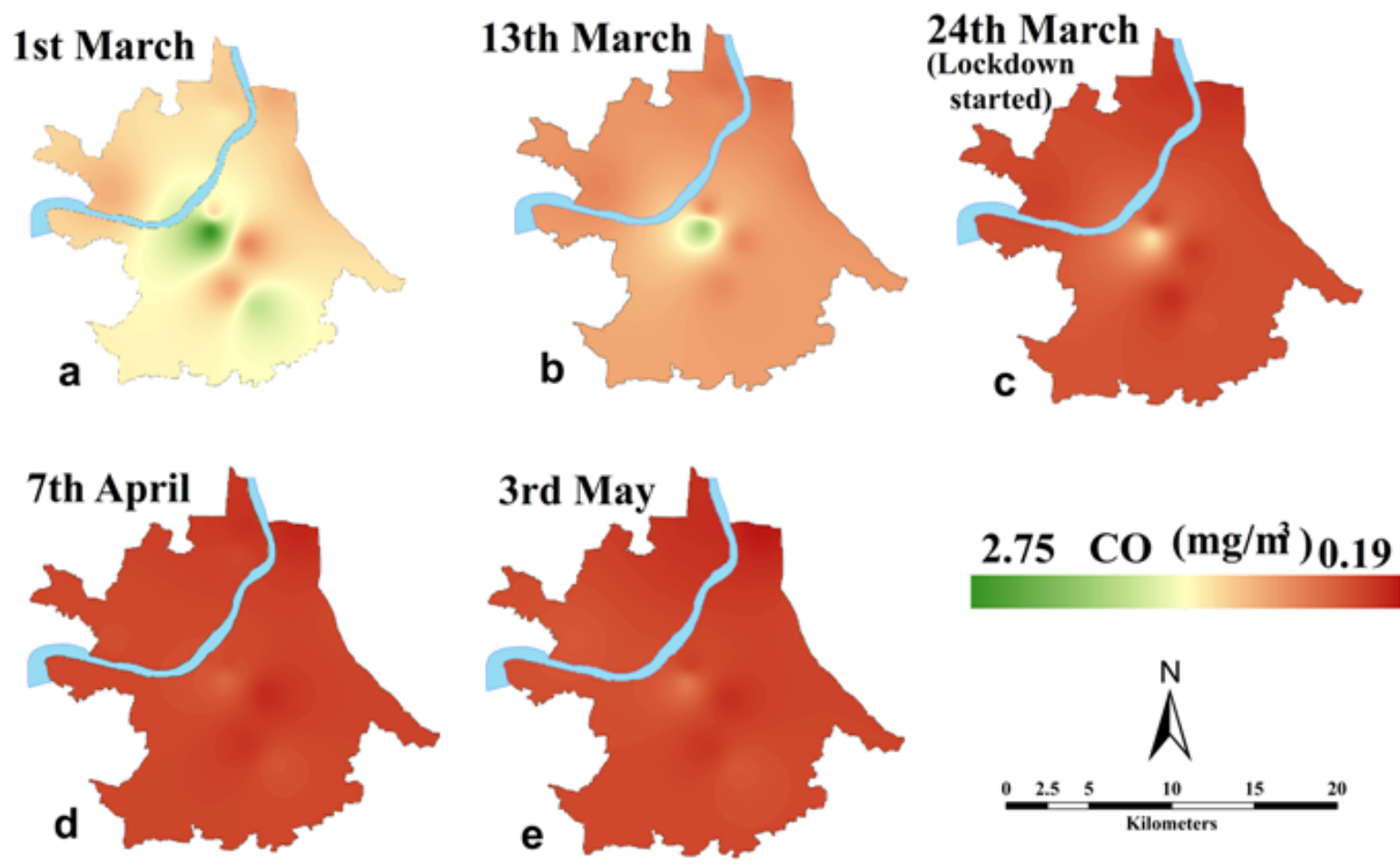

Figure 12

Spatio-temporal change of CO (2020)
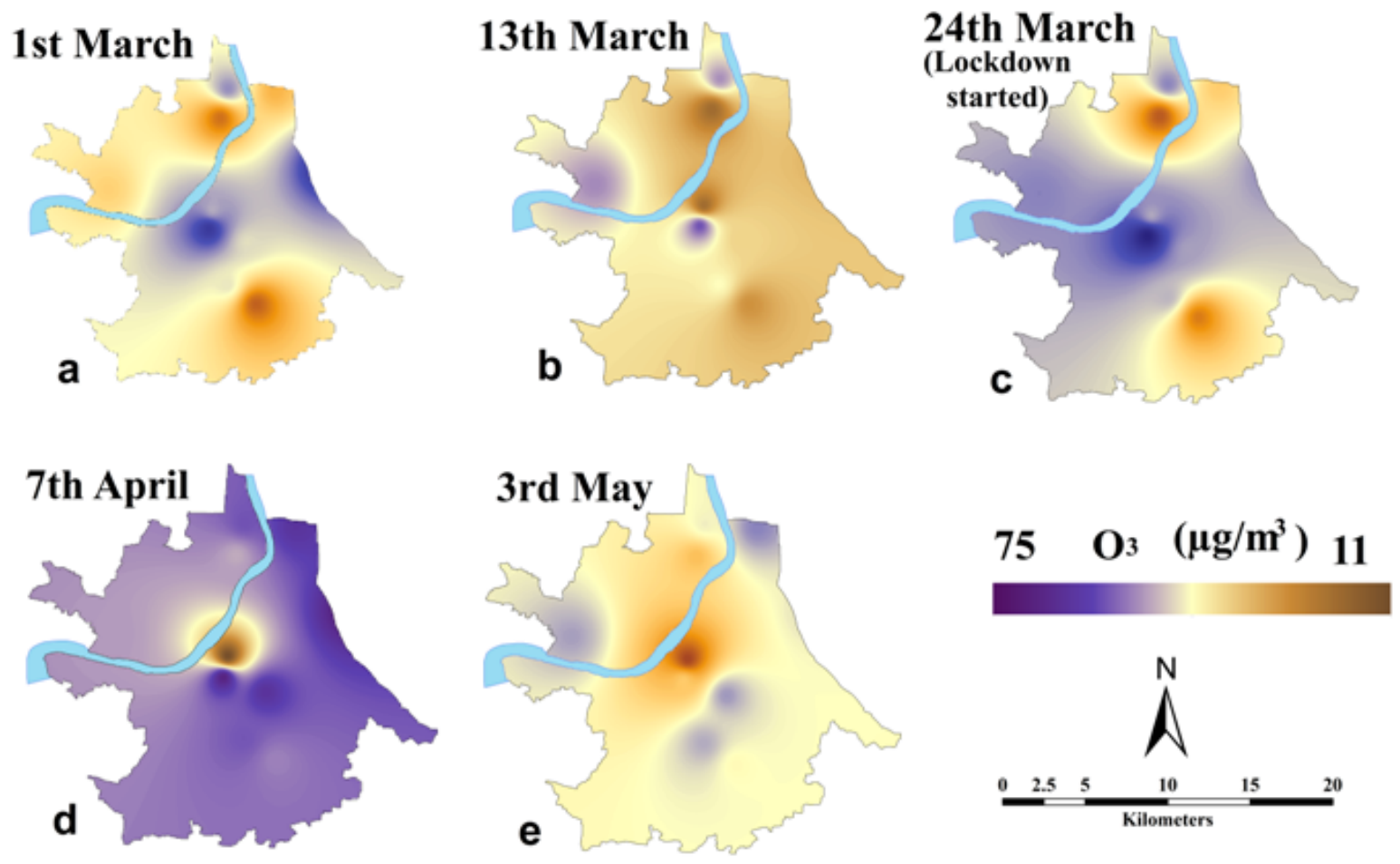

Figure 13 

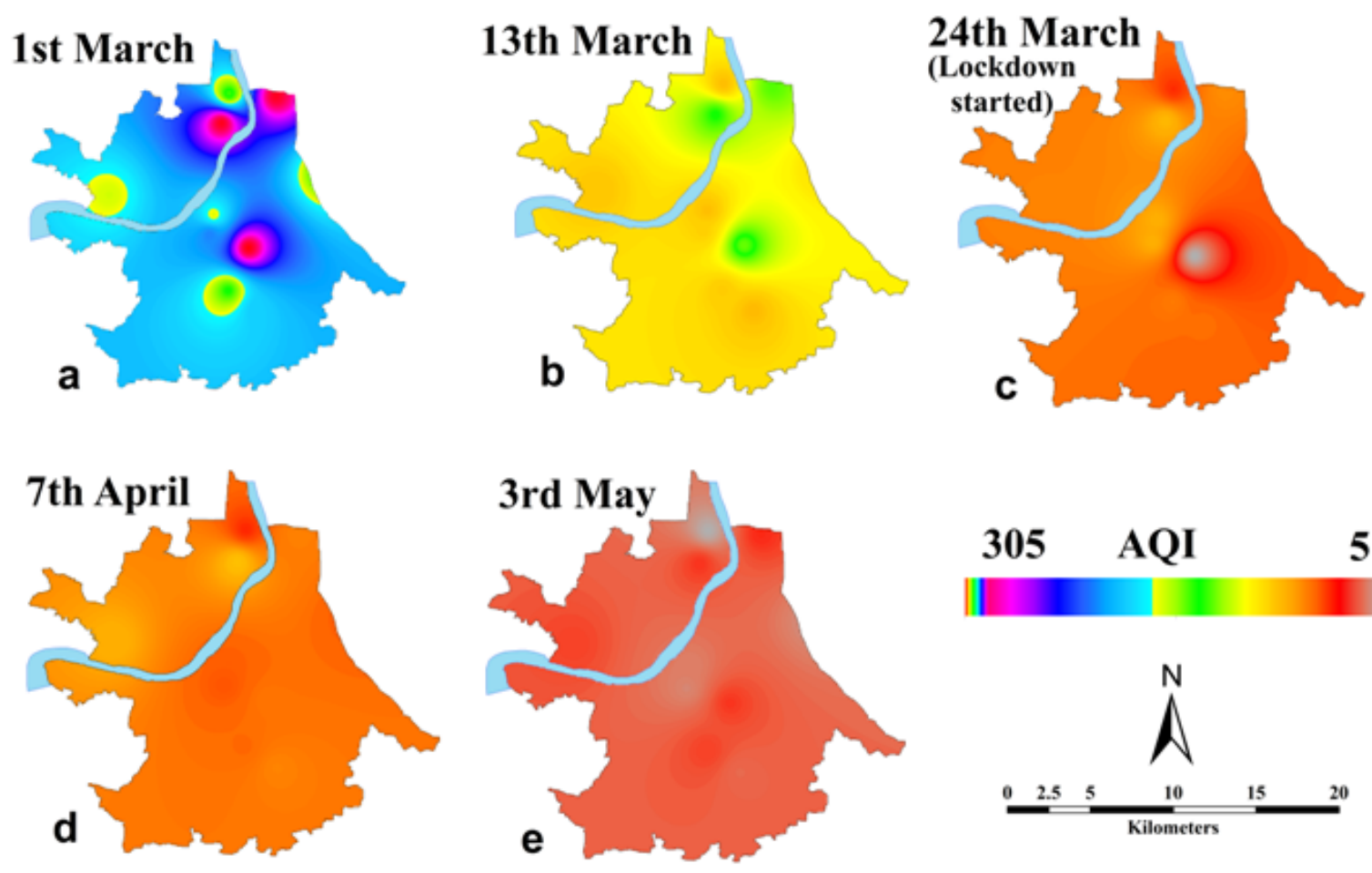

Figure 14

Spatio-temporal change of AQI (2020)

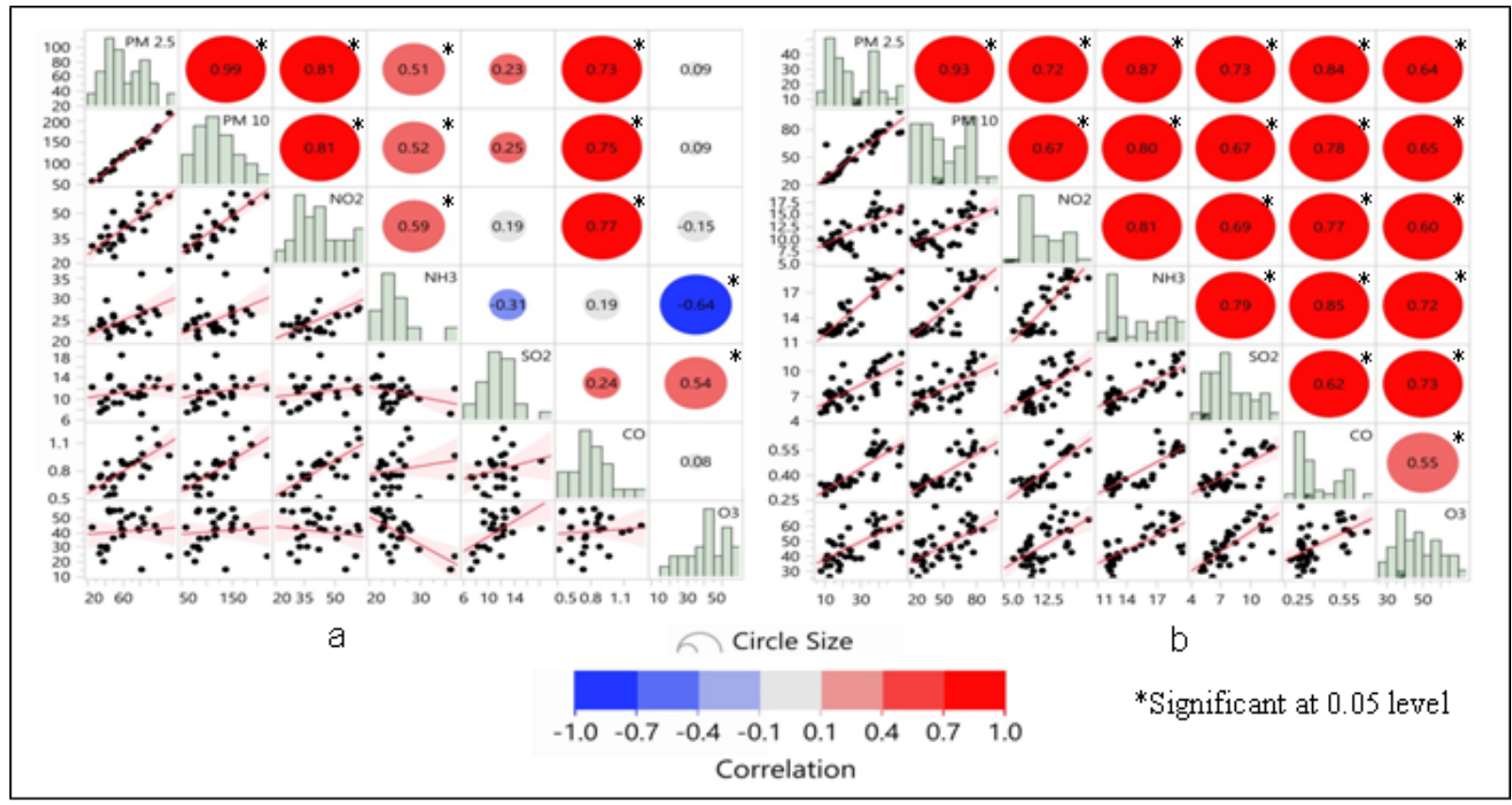


Correlation among the pollutants during the (a) pre-lockdown and (b) during the lockdown period

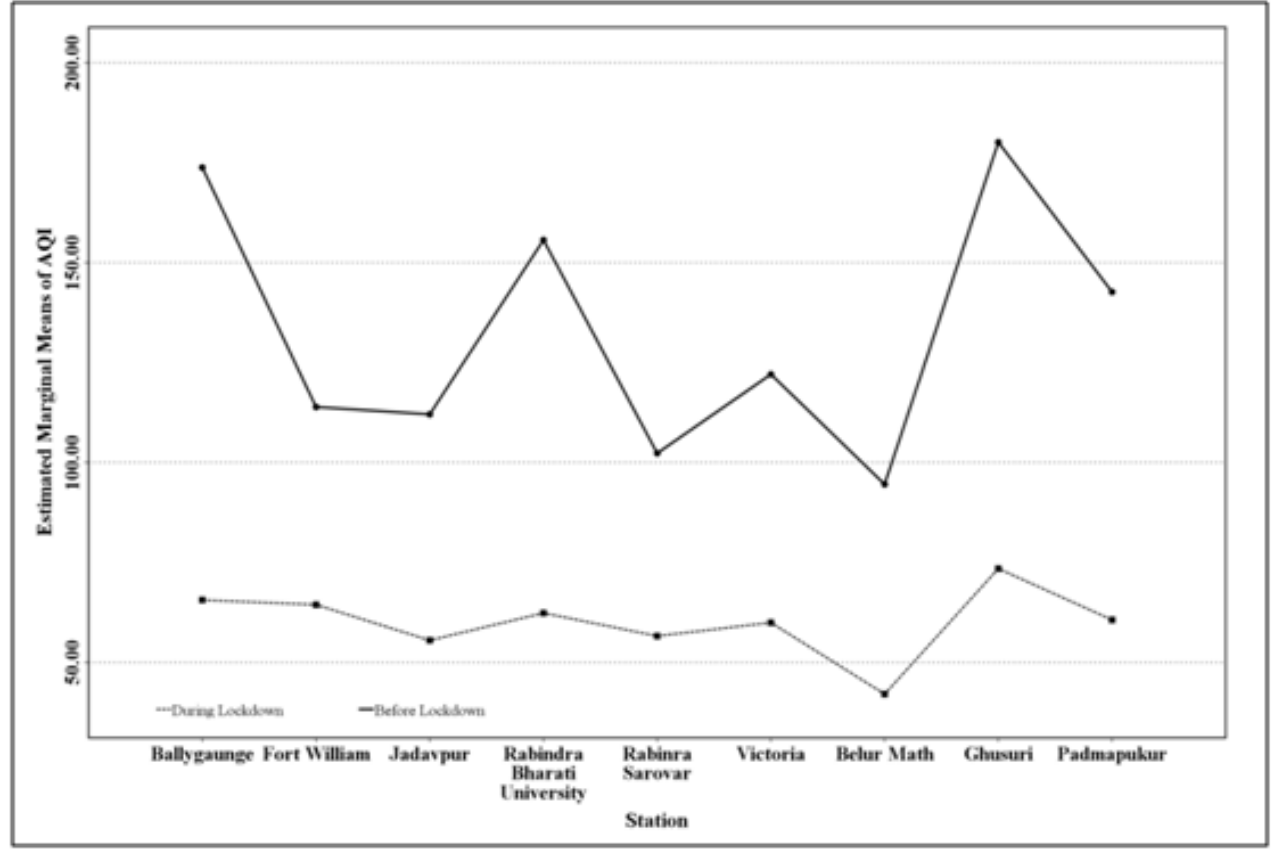

Figure 16

Mean difference of each station between the pre-lockdown and during-lockdown. 